Article

\title{
Supporting Policy Design for the Diffusion of Cleaner Technologies: A Spatial Empirical Agent-Based Model
}

\author{
Caterina Caprioli * $\left(\mathbb{D}\right.$, Marta Bottero $\mathbb{D}^{\mathbb{B}}$ and Elena De Angelis \\ Politecnico di Torino, Interuniversity Department of Regional and Urban Studies and Planning (DIST), \\ Viale Mattioli 39, 10125 Torino, Italy; marta.bottero@polito.it (M.B.); elena.deangelis@polito.it (E.D.A.) \\ * Correspondence: caterina.caprioli@polito.it; Tel.: +39-0110906468
}

Received: 23 August 2020; Accepted: 28 September 2020; Published: 1 October 2020

\begin{abstract}
Renewable energy resources and energy-efficient technologies, as well as building retrofitting, are only some of the possible strategies that can achieve more sustainable cities and reduce greenhouse gas emissions. Subsidies and incentives are often provided by governments to increase the number of people adopting these sustainable energy efficiency actions. However, actual sales of green products are currently not as high as would be desired. The present paper applies a hybrid agent-based model (ABM) integrated with a Geographic Information System (GIS) to simulate a complex socio-economic-architectural adaptive system to study the temporal diffusion and the willingness of inhabitants to adopt photovoltaic (PV) systems. The San Salvario neighborhood in Turin (Italy) is used as an exemplary case study for testing consumer behavior associated with this technology, integrating social network theories, opinion formation dynamics and an adaptation of the theory of planned behavior (TPB). Data/characteristics for both buildings and people are explicitly spatialized with the level of detail at the block scale. Particular attention is given to the comparison of the policy mix for supporting decision-makers and policymakers in the definition of the most efficient strategies for achieving a long-term vision of sustainable development. Both variables and outcomes accuracy of the model are validated with historical real-world data.
\end{abstract}

Keywords: Geographic Information System (GIS); sustainable development; eco-district; photovoltaic system; innovation diffusion; energy; decision-making process; consumer behavior; social network; theory of planned behavior

\section{Introduction}

Urban policy is an increasingly relevant domain aimed at coping with the complexity of urban problems in an overall perspective [1]. Normally, urban problems are characterized by multiple conflicting aspects and incommensurable elements, as well as by multiple stakeholders, thus requiring even more tools and methods able to synthetize a full set of factors for supporting policymakers and defining efficient strategies.

Moreover, the increasing pressure of the state of transition of our cities through the sustainable development model implies an urgent need to identify and evaluate the environmental, economic, and social impacts of alternative policies and actions [2]. Cities are, in fact, responsible for more than $70 \%$ of energy-related emissions and $60-80 \%$ of final energy use is consumed in cities [3]; at the same time, they represent the main place of attraction for people, technological, economic and socio-cultural development [4]. Many market surveys have demonstrated a very positive attitude towards eco-innovations and sustainability, but depite this, sales of green products are currently not as high as would be desired [5]. Consequently, in recent decades, many directives, programs and 
frameworks have been adopted and supported by the European Union for promoting sustainable development [6]. One of the most recent and relevant of these is the 2030 Agenda for Sustainable Development with 17 sustainable development goals (SDGs) adopted in 2015, which amounts to an urgent call for action to all countries. SDG 11- "Sustainable cities and communities"-is devoted to the design of future cities able to generate social inclusion and mutual respect in the interaction between people and their surrounding environment. Since this goal refers explicitly to the inherent interrelation between communities and their living space, the "people" perspective is of utmost importance, and requires specific tools. The agent-based model (ABM) is an extremely powerful tool, suitable in different fields $[7,8]$ and, in particular, in decision making. It considers individual behaviors and networking among people, together with real-world data in a multi-temporal and spatial dimension.

Policy design can deal with sectoral policies, which are implemented across different territories, or, on the other hand, with area-based policies implemented at a more specific scale (such as neighborhood) [1]. The term "neighborhood" is often blurred. The scale and characteristics of neighborhoods vary a lot around the world, and this has consequences on the area-based policies adopted. The internal dynamics within a given neighborhood combine with the multi-dimensionality of urban problem, and require multiple policy strategies and the engagement of both public and private stakeholders [9]. The area under analysis in the present study is an officially recognised neighborhood defined by the city of Turin for administrative purposes, whose boundaries clearly separate the district from the other parts of the city, for the presence of the station to the west, the main hospital of the city to the south, the Po river to the east and the city center to the north. This neighborhood has been chosen by the municipality of Turin as a test-bed place for creating a so-called eco-district in the city of Turin and experimenting sustainable strategies and policies to be then spread to the overall municipality. As testified by many eco-districts and sustainable neighborhoods which have been developed all over the world [10], the neighborhood scale represents a good compromise as a scale for testing efficient strategies and policies [11].

More than other scales, sustainable neighborhood policies require a spatial approach, with an analysis of detailed information and finer data on buildings and inhabitants. Decision-makers need appropriate tools to structure problems, to plan and evaluate alternatives in a multi-temporal, multi-objective and long-term perspective. In that context, mixed methods have even more important for supporting the decision process and the definition of efficient policies, contributing to the consideration of multiple elements and feedbacks of stakeholders at the same time.

The present research investigates the potentialities of a mixed-method approach, which combines an agent-based model (ABM) with a Geographic Information System (GIS), in supporting the decision-making process and the definition of strategic policies. The integration of individual behavior simulations through the adoption of ABM, and the real-world spatial distribution of data and people through GIS is particularly promising although it is not well codified either in simulation analyses or policy design. The choice of ABM is due to its many abilities. Firstly, it is possible to perform analysis at different scales, spanning from a finer scale, such as single buildings or districts, to a wider scale, including cities and entire countries. Secondly, it is able to integrate real spatial data of a specific context related both to environmental characteristics (such as building properties, services localization, pollutants distribution) and data on individuals (such as income, attitude, needs, age). It is particularly necessary to consider people as single agents with their own decision rules and personal attributes located in a real-world space, rather than looking at them in terms of statistics. Thirdly, time represents a fundamental element in understanding the effects of actions and policies over a timeframe. By taking time into consideration, it is possible to predict the impact of single or multiple features within a given timeframe. Over time, the model simulates consumer behavior in the adoption of photovoltaic (PV) systems by integrating real geospatial data with social network theories, opinion dynamics formation and individual preferences of homeowners. The San Salvario neighborhood in the city of Turin (Italy) is used as an exemplary case study for testing the pros and 
cons of this hybrid evaluation method. The "exploratory simulation" [12] capability of ABM makes them extremely useful in studying complex systems, becoming like a sort of virtual laboratory, where multiple simulation sessions occur, varying inputs and changing attributes [13].

The paper is structured as follow: after this introduction, the materials and methods section describes the main behavioral theories applied in the model, as well as the main references used for defining the variables considered in the simulation. Then, in the application section, the case study is presented with a specific focus on how the model was set up, the variables considered, and the set of data acquired. The results section illustrates the outcomes of the research and the role of the policy mix for achieving more successfully policies. In particular, the results accuracy is validated with historical real-world data and sensitivity analysis/parameters sweeping across the variables selected. Finally, the last section contains the concluding remarks of the analysis and the future perspectives of the research.

\section{Materials and Methods}

\subsection{Literature Review}

ABM has been extensively used to study the diffusion of innovation, also in the context of innovation technologies at the urban scale. To name a few of them, it is possible to recall the research of Sopha et al. (2013) [14] and the paper by Snape et al. (2015) [15] on heating systems diffusion or the one by Byrka et al. (2016) [5] on green products and practices. Frequently, these analyses have been conducted also for supporting policymakers in the evaluation of possible interventions and the effects of alternative policies. These claims are supported by existing literature reviews on the use of ABM for studying innovation diffusion performed in the last ten years, such as the first by Kiesling et al. (2012) [16], the one by Zhang and Vorobeychik (2017) [17] and the most recent on energy-efficient technologies by Hesselink and Chappin (2019) [18]. The first two reviews highlight a general attitude of authors in developing theoretical models with limited prediction capacity. However, some initial efforts to perform empirical ABM for analyzing innovation diffusion are classified by Kiesling (2012) [16] in three domains: agriculture (a) energy, transportation and environmental innovations (b) and miscellaneous (c). The review of Zhang and Vorobeychik (2017) [17] adds to the three classifications of Kiesling's (2012) [16] other two issues: agricultural innovations and farming (a), sustainable energy and conservation technologies (b), consumer technologies and innovations (c), information technologies (d) and social goods (e). Concerning the second cluster, Zhang and Vorobeychik (2017) [17] report 21 documents to which Hesselink and Chappin (2019) [18] add another 17 papers. This list makes clear the increasing and strong efforts and interest of the research on the topic of innovation diffusion, in particular in the context of energy and environmental innovations.

In the specific framework of this research, it is also possible to state that precisely in the PV system diffusion and the definition of related policies, there is a very recent and increasing interest in ABM adoption, as testified for example by the recent papers by Haelg et al. (2018) [19], Lee and Hong (2019) [20], Schiera et al. (2019) [21], Nuñez-Jimenez et al. (2020) [22]. However, other previous examples also show the strong effort of the research in this context (such as [23-26]).

Table 1 reports the main documents in which ABM is applied for analyzing the temporal diffusion of innovative technologies and used for defining the methodological framework of our analysis (Table 2). Table 1 is precisely focused on the main theoretical models used in those research studies, the time and scale of simulations - in particular, if GIS was applied and in which way-the identification of the analyzed policies, as well as the variables considered and the level of detail of people characteristics. In Table 1, the elements used in our simulation model are highlighted in grey. Then, Table 2 reports the mixed ABM used in the present research, also showing the innovativeness of the analysis over the others. 
Table 1. Main references on photovoltaic (PV) diffusion used for defining the methodological framework of the research (adapted and integrated from Schiera et al. (2019)).

\begin{tabular}{|c|c|c|c|c|c|c|c|c|c|}
\hline Authors & $\begin{array}{l}\text { Behavior } \\
\text { Model }^{1}\end{array}$ & $\begin{array}{l}\text { Time }^{2} \\
\text {-Timeframe }\end{array}$ & Scale & $\begin{array}{l}\text { Model } \\
\text { Purpose }\end{array}$ & Policy & Variables & $\begin{array}{l}\text { Geographic } \\
\text { Information } \\
\text { System (GIS) }\end{array}$ & Agents Initialization & $\begin{array}{l}\text { Data } \\
\text { Validation }\end{array}$ \\
\hline $\begin{array}{l}\text { Bottaccioli et al. } \\
\text { (2019) [21] }\end{array}$ & $\begin{array}{l}\text { TPB + RA + } \\
\text { SWN }\end{array}$ & $\mathrm{Q}-20$ years & $\begin{array}{l}\text { District/ } \\
\text { household }\end{array}$ & Policy design & $\begin{array}{l}\text { (1to1) actual Italian } \\
\text { regulatory } \\
\text { framework vs. } \\
\text { (1toM) joint } \\
\text { self-consumption } \\
\text { citizen (Clean } \\
\text { Energy } \\
\text { package [27]) }\end{array}$ & $\begin{array}{ll}\text { - } & \text { Opinion uncertainty } \\
\text { - Innovation } \\
\text { - } & \text { Income } \\
\text { - } & \text { Payback period } \\
& \text { electricity consumption, rates, } \\
& \text { PV generation }\end{array}$ & $\begin{array}{l}\text { Yes, block } \\
\text { scale }\end{array}$ & $\begin{array}{l}\text { Italian statistics } \\
\text { characteristics }\end{array}$ & $\begin{array}{l}\text { Sensitivity of } \\
\text { the attributes }\end{array}$ \\
\hline $\begin{array}{l}\text { Lee and Hong } \\
2019 \text { [20] }\end{array}$ & $\begin{array}{l}\text { LR/PL + peer } \\
\text { effect }\end{array}$ & $Y-9$ years & $\begin{array}{l}\text { District/ } \\
\text { household }\end{array}$ & $\begin{array}{l}\text { Diffusion } \\
\text { study }\end{array}$ & - & $\begin{array}{l}\text { Building type, total } \\
\text { rooftop area, gross floor } \\
\text { area, and year of approval } \\
\text { Density, average age, } \\
\text { and officially assessed } \\
\text { land price } \\
\text { Technical performances } \\
\text { of the rooftop solar } \\
\text { PV system } \\
\text { - Economic performance of } \\
\text { the rooftop PV } \\
\text { - Payback period }\end{array}$ & $\begin{array}{l}\text { Yes, block } \\
\text { scale }\end{array}$ & Census block data & $\begin{array}{l}\text { Empirical } \\
\text { data-driven } \\
\text { behavioral } \\
\text { rules of } \\
\text { rooftop solar } \\
\text { PV adoption }\end{array}$ \\
\hline $\begin{array}{l}\text { Nuñez-Jimenez et al. } \\
\text { (2020) [22] }\end{array}$ & $\begin{array}{l}\mathrm{TF} / \mathrm{UF}+\text { peer } \\
\text { effects }\end{array}$ & $Y-6$ years & State & $\begin{array}{l}\text { Policy } \\
\text { evaluation }\end{array}$ & $\begin{array}{l}\text { Adjusting } \\
\text { incentives: } \\
\begin{array}{ll} & \\
\text { - } & \text { Deployment } \\
\text { (EUR/kWh } \\
\text { per MWp) } \\
\text { - Policy cost } \\
\text { (EUR/kWh per } \\
\text { EUR million) } \\
\text { Profitability } \\
\text { (EUR/kWh) }\end{array}\end{array}$ & $\begin{array}{ll}\text { - } & \text { Available information } \\
& \text { about PV } \\
\text { - } & \text { Environmental awareness } \\
\text { - } & \text { Investing attractiveness }\end{array}$ & No & $\begin{array}{l}\text { Electricity consumers in } \\
\text { Germany }\end{array}$ & $\begin{array}{l}\text { Calibration of } \\
\text { the attributes } \\
\text { (historical } \\
\text { cumulative } \\
\text { installations } \\
\text { between } 1992 \\
\text { and 2016) }\end{array}$ \\
\hline
\end{tabular}


Table 1. Cont

\begin{tabular}{|c|c|c|c|c|c|c|c|c|c|}
\hline Authors & $\begin{array}{l}\text { Behavior } \\
\text { Model }^{1}\end{array}$ & $\begin{array}{l}\text { Time }^{2} \\
\text {-Timeframe }\end{array}$ & Scale & $\begin{array}{l}\text { Model } \\
\text { Purpose }\end{array}$ & Policy & Variables & $\begin{array}{l}\text { Geographic } \\
\text { Information } \\
\text { System (GIS) }\end{array}$ & Agents Initialization & $\begin{array}{l}\text { Data } \\
\text { Validation }\end{array}$ \\
\hline $\begin{array}{l}\text { Rai and Robinson } \\
2015 \text { [26] }\end{array}$ & $\begin{array}{l}\text { TPB }(\text { partial })+ \\
\text { RA }\end{array}$ & $Q-6$ years & $\begin{array}{l}\text { State/ } \\
\text { household }\end{array}$ & Policy design & $\begin{array}{l}\text { - Rebate/price } \\
\text { changes on the } \\
\text { level of } \\
\text { PV adoption } \\
\text { Low-income } \\
\text { solar program }\end{array}$ & 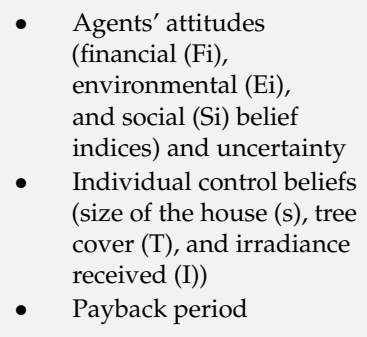 & $\begin{array}{l}\text { Yes, } \\
\text { distribution } \\
\text { with linear } \\
\text { regression and } \\
\text { results } \\
\text { (city-level } \\
\text { median) }\end{array}$ & $\begin{array}{ll}\text { - } & \text { System details, location, } \\
\text { installation date, etc. } \\
\text { - } \quad \text { Survey on } \\
\text { installation decision } \\
\text { - } \quad \text { Home value, parcel size, } \\
\text { land-use code, etc. } \\
\text { - } \quad \text { Light Detection and } \\
\text { Ranging (LIDAR) } \\
\text { images and National } \\
\text { Elevation Dataset }\end{array}$ & $\begin{array}{l}\text { Calibration of } \\
\text { the attributes } \\
\text { (empirical } \\
\text { adoption } \\
\text { levels } \\
\text { between 2008 } \\
\text { and 2013) }\end{array}$ \\
\hline $\begin{array}{l}\text { Rai and Sigrin } \\
2013[25]\end{array}$ & FE & $Y-25$ years & State & $\begin{array}{l}\text { Financial } \\
\text { decision-process } \\
\text { of consumers }\end{array}$ & & $\begin{array}{l}\text { - Income } \\
\text { Electricity consumption, } \\
\text { electricity rates, } \\
\text { PV generation }\end{array}$ & No & $\begin{array}{l}\text { Homogeneous (income, age, } \\
\text { degree) }\end{array}$ & $\begin{array}{l}5 \text { Scenarios on } \\
\text { electricity and } \\
\text { PV system }\end{array}$ \\
\hline $\begin{array}{l}\text { Robinson et al. } \\
\text { (2013) [24] }\end{array}$ & $\begin{array}{l}\text { TPB + RA + } \\
\text { SWN }\end{array}$ & Q & $\begin{array}{l}\text { District/ } \\
\text { household }\end{array}$ & $\begin{array}{l}\text { Diffusion } \\
\text { study }\end{array}$ & - & $\begin{array}{ll}\text { - } & \text { Opinion on PV } \\
\text { - } & \text { Environmental awareness } \\
\text { - } & \text { Paybome } \\
& \end{array}$ & $\begin{array}{l}\text { Yes, block } \\
\text { scale }\end{array}$ & $\begin{array}{l}\text { Social, economic, } \\
\text { demographic and behavioral } \\
\text { attributes of Austin (Texas) } \\
\text { population (not more } \\
\text { specified) }\end{array}$ & $\begin{array}{l}\text { Calibration of } \\
\text { the attributes } \\
\text { based on } \\
\text { historical data } \\
\text { of adoption } \\
\text { (2005-2008) }\end{array}$ \\
\hline $\begin{array}{l}\text { Zhao et al. } \\
2011[23]\end{array}$ & $\mathrm{TF}$ & $\mathrm{M}-21$ years & Region & $\begin{array}{l}\text { Policy } \\
\text { evaluation }\end{array}$ & $\begin{array}{l}\text { Two incentives } \\
\text { (Investment Credit } \\
\text { Tax and Feed-in } \\
\text { Tariff) }\end{array}$ & $\begin{array}{l}\text { - } \quad \text { Payback period } \\
\text { Electricity generation } \\
\text { (PV) and consumptions, } \\
\text { incentive levels, PV } \\
\text { module price, and hourly } \\
\text { electricity price (grid) } \\
\text { - Income } \\
\text { - Word-of-mouth effect } \\
\text { - } \\
\text { Advertisement effect }\end{array}$ & No & U.S. Census Bureau & $\begin{array}{l}\text { Sensitivity on } \\
\text { the attributes } \\
\text { and real } \\
\text { statistical data }\end{array}$ \\
\hline
\end{tabular}

${ }^{1} \mathrm{TPB}=$ theory of planned behavior, $\mathrm{RA}=$ relative agreement, $\mathrm{SWN}=$ small-world network, $\mathrm{LR}=$ logistic regression, $\mathrm{PL}=$ adoption probability level; $\mathrm{UF}=\mathrm{utility}$ function, $\mathrm{TF}=\mathrm{threshold}$ function, $\mathrm{FN}=$ financial evaluation; ${ }^{2} \mathrm{Y}=$ yearly, $\mathrm{Q}=$ quarterly, $\mathrm{M}=$ monthly, $\mathrm{W}=$ weekly. 
Table 2. The framework of the model performed in the present research based on the literature review.

\begin{tabular}{|c|c|c|c|c|c|c|c|c|c|}
\hline Authors & $\begin{array}{l}\text { Behavior } \\
\text { Model }\end{array}$ & Time-Timeframe & Scale & $\begin{array}{l}\text { Model } \\
\text { Purpose }\end{array}$ & Policy & Variables & GIS & Agents Initialization & Data Validation \\
\hline Our model & $\begin{array}{l}\mathrm{TPB}+\mathrm{RA}+ \\
\mathrm{SWN}\end{array}$ & $Y-30$ years & District & $\begin{array}{l}\text { Policy } \\
\text { design }\end{array}$ & $\begin{array}{ll}\text { - } & \text { Actual Italian } \\
\text { regulatory framework } \\
\text { - } \quad \text { Vouchers from PV } \\
\text { sellers to adopters for } \\
\text { sharing with "friends" } \\
\text { - Low-income incentives } \\
\text { - Information diffusion } \\
\text { (both environmental } \\
\text { awareness and } \\
\text { technology information) }\end{array}$ & $\begin{array}{ll}\text { - } & \text { Opinion uncertainty } \\
\text { - } & \text { Environmental awareness } \\
\text { - } & \text { Enformation technology } \\
& \text { awaronmental } \\
\text { - } & \text { Innovation } \\
\text { - } & \text { Income } \\
\text { - } & \text { Return on investment } \\
\text { - } & \text { Electricity consumption, } \\
& \text { electricity rates, PV } \\
& \text { generation, PV rates } \\
\text { - } & \text { Payback period }\end{array}$ & $\begin{array}{l}\text { Yes, block } \\
\text { scale }\end{array}$ & $\begin{array}{l}\text { - San Salvario spatialized } \\
\text { people characteristics at } \\
\text { block scale (degree, } \\
\text { number of components, } \\
\text { occupation, } \\
\text { rent/owner, nationality) } \\
\text { Italian } \\
\text { statistics characteristics }\end{array}$ & $\begin{array}{l}\text { Calibration of the } \\
\text { attributes based on } \\
\text { historical data of } \\
\text { adoption (2011-2019) } \\
\text { and sensitivity of the } \\
\text { attributes }\end{array}$ \\
\hline
\end{tabular}




\subsection{A Mixed Hybrid Agent-Based Model (ABM)}

The present research proposes a mixed hybrid agent-based model, which combines the small world network (SWN) theory [28] and the relative agreement (RA) opinion formation dynamics [29,30] into an adapted theory of planned behavior (TPB) [31], using a rich set of real-world data and a spatial representation through the integration of GIS maps. These combinations of theories and assumptions were used to develop the individual single-family households calculation for the adoption of the PV systems.

\subsubsection{Theory of Planned Behavior}

The theory of planned behavior (TPB) was developed by Ajzen in the 1970s and performed next in 1991 [31]. This theory still represents one of the most commonly used approaches in social sciences to predict people's intentions to perform a behavior. Thus, it is particularly useful for studying the diffusion of innovations, as testified by several very recent applications, such as [21,32,33]. According to Ajzen, the intention "can be predicted with high accuracy from attitudes toward the behavior, subjective norms, and perceived behavioral control" [31], as shown in Figure 1 [34].

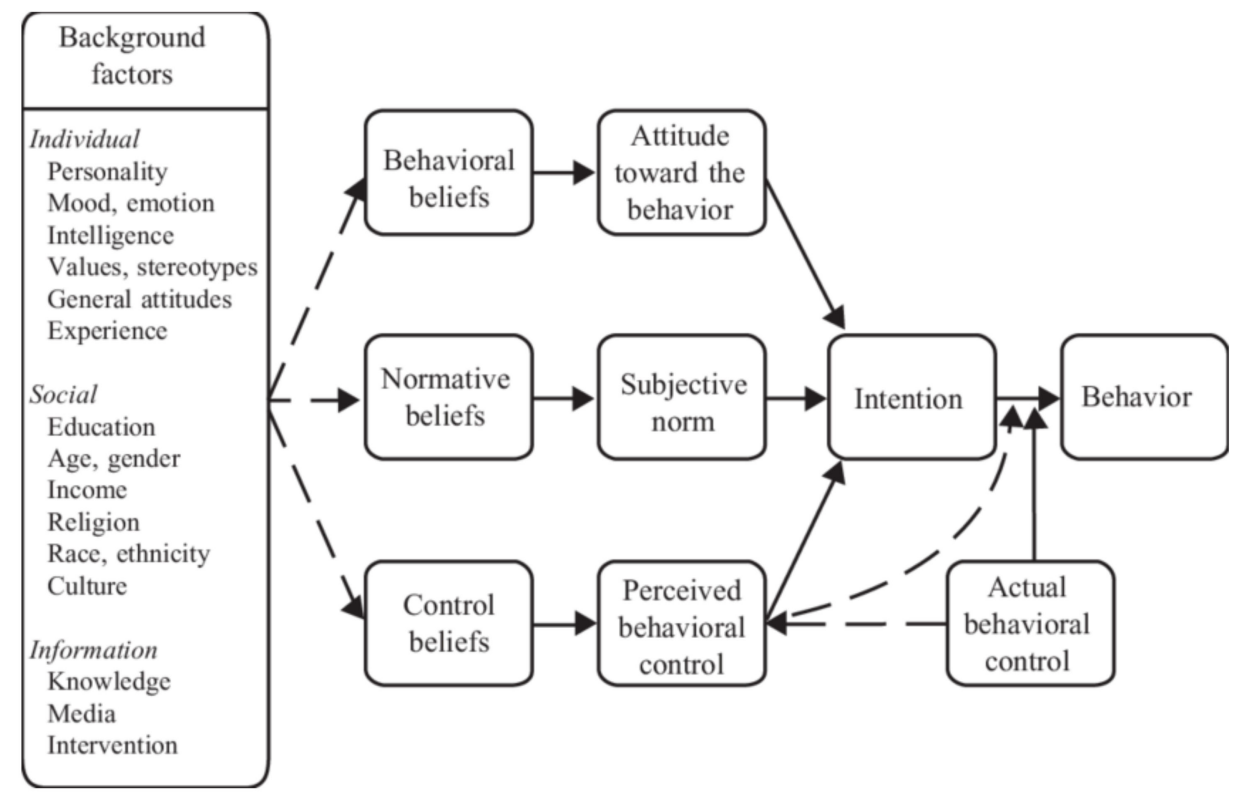

Figure 1. The theory of planned behavior framework (Fishbein and Ajzen, 2005).

Individual factors (such as personality, emotion, values, experience, intelligence), social aspects (such as education, age, gender, income, religion, race, ethnicity and culture) and information (such as knowledge or media) contribute together to the formation of beliefs, which are at the basis of attitude toward the behavior, subjective norm and perceived behavioral control formation.

A favorable or unfavorable attitude toward the behavior (att) is represented by the behavioral beliefs, i.e., "the likely outcomes of the behavior and the evaluation of these outcomes" [35]. Personality, emotion, values, experience, intelligence are some examples of factors that influence the formation of the attitude toward the behavior.

Subjective norm (also called perceived social pressure) $(s n)$ is the result of normative beliefs which are connected to the "normative expectations of others and motivation to comply with these expectations" [35]. This means that individuals are influenced in different ways by those people who are important to them, such as family and friends, or the community of people around them, as well as by government and the common sense and feel of their community. The social and job position of individuals can also influence their choice: the motivation to comply can be stressed by what people do for the position they have. 
Perceived behavioral control $(p b c)$ derives from control beliefs, i.e., "factors that may facilitate or impede the performance of the behavior and the perceived power of these factors" [35].

These three components contribute to the formation of the intention to the behavior, as reported in the Equation (1):

$$
b i=a t t \cdot W_{a t t}+s n \cdot W_{s n}+p b c \cdot W_{p b c}
$$

where $a t t, s n$ and $p b c$ are the three components explained before, Watt, $W s n$ and $W_{p b c}$ are, respectively, the weights for distinguishing between the level of importance given to $a t t, s n$ and $p b c$ by each individual.

Finally, the final behavior $(B)$ is given by "a sufficient degree of actual control (act) over the behavior" which people have "to carry out their intentions when the opportunity arises" [35] and formulated as follows:

$$
b=b i \cdot W b i+a c t \cdot W a c t
$$

where $b i$ is the intention of the behavior explained in Equation (1), act is the actual control, whereas $W b i$ and Wact are, respectively, the weights assigned by the individual for these two components.

\subsubsection{Opinion Formation}

As underlined by Deffuant et al. (2000) [30], the opinion dynamics model is mostly based on binary opinions (such as [30,36-39]), which social actors modify according to social influence or their own experience. We can consider opinion as a continuous variable in time, which can also influence the final behavior of individuals. In the present model, opinion formation dynamics were used to perform the evolution mechanism of the word of mouth, which directly influences the definition of the attitude toward the behavior and the social norm of TPB. In the present model, opinion formation dynamics follow the relative agreement (RA) algorithm, proposed by Deffuant et al. in 2002 [29], which combines a degree of uncertainty to the opinion of individuals.

According to this model, each individual (agent $i$ ) is characterized by two variables, an opinion $x_{i}$ and an uncertainty $u_{i}$. Both opinion and uncertainty are real numbers, but the opinion varies between -1 and 1 and uncertainty between 0 and 2. Graphically, they are represented by a point on an axis and a segment, respectively, as is possible to see in Figure 2. The theory supposed that random pair interactions among the agents can influence (and can update) each other's opinion (and uncertainty). In particular, as can be seen in Figure 2, the change in the opinion $x_{j}$ of agent $j$ is due to the influence of agent $i$ and it is proportional to the overlap $\left(h_{i j}\right)$ between both segments (the agreement $a_{i j}$ ) divided by the uncertainty of the influencing segment (for that reason the method is called "relative" agreement $\left.r a_{i j}\right)$ [29].

BEFORE INTERACTION

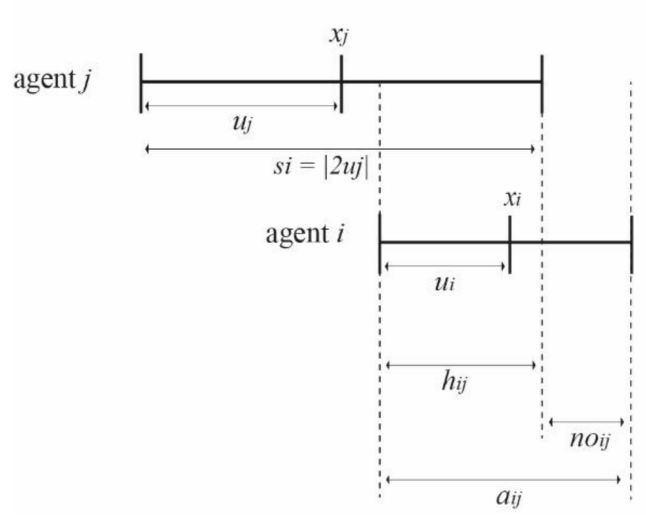

AFTER INTERACTION

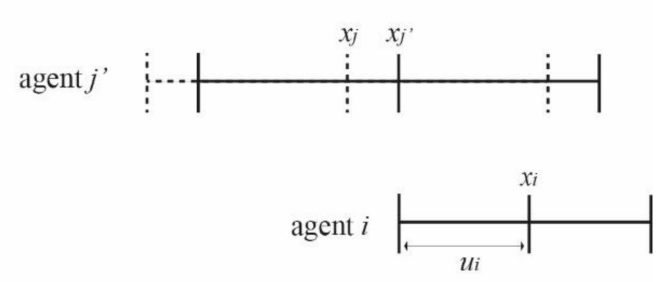

Figure 2. The influence of individual $i$ on individual $j$ based on the "relative agreement rules" (adapted from Deffuant et al. (2002)).

The calculation to obtain the updated opinion and uncertainty is reported below: 
- The overlap $h_{i j}$ is given by:

$$
h_{i j}=\min \left(x_{i}+u_{i}, x_{j}+u_{j}\right)-\max \left(x_{i}-u_{i}, x_{j}-u_{j}\right)
$$

- The non-overlapping $\left(n o_{i j}\right)$ :

$$
n o_{i j}=2 u_{i}-h_{i j}
$$

- The agreement $\left(a_{i j}\right)$ is the overlap minus the non-overlap:

$$
a_{i j}=2 *\left(h_{i j}-u_{i}\right)
$$

- The relative agreement is the agreement divided by the length of segment $s i$, which corresponds to the double of the abs value of the uncertainty of agent $i$ :

$$
r a_{i j}=\frac{2 *\left(h_{i j}-u_{i}\right)}{2 * u_{i}}=\frac{h_{i j}}{u_{i}}-1
$$

If $h_{i j}>u_{i}$, the variation of agent $j^{\prime}$ s opinion $\left(x_{j}^{\prime}\right)$ and uncertainty $\left(u_{j}^{\prime}\right)$ due to the interactions is significant and it is updated as follows:

$$
\begin{aligned}
& x_{j}^{\prime}=x_{j}+\mu *\left(\frac{h_{i j}}{u_{i}}-1\right) *\left(x_{i}-x_{j}\right) \\
& u_{j}^{\prime}=u_{j}+\mu *\left(\frac{h_{i j}}{u_{i}}-1\right) *\left(u_{i}-u_{j}\right)
\end{aligned}
$$

The same process and updating occur per each pair interaction among agents.

\subsubsection{Social Network Theories}

The process of pair interactions at the basis of the RA algorithm needs to be more formalized in the context of real-world case study, such as the one in the present research. The way how two random agents start to interact generally happens for similarity features of agents and/or for their proximity. Many theories were developed along the time on the social networking formation, also connected with ABM development, spanning from neighborhood model (von Neumann "5-neighbour" or Moore "9-neighbour" [40]) to the 2D or 3D Euclidean Space [7], from Network structure (such as Scale-Free Network and the most recent Preferential Attachment [41], or the Small-World [28]) to GIS topology. An in-depth analysis on the model of interaction is, therefore, strongly necessary since interaction represents one of three key elements of $\mathrm{ABM}$ (together with the agents themselves and the environment).

The present paper adopted the small-world networks (SWNs) developed by Watts and Strogatz in 1998 [28] adapted to a real-world environmental of agents whose distance is determined by information contained into GIS maps. The name "small-world" is properly an analogy to the small-world phenomenon [42,43] known as six degrees of separation [44]. SWN represents an intermediate network between a regular network and a complete disorder network, where $p$ is the probability of randomness interactions among agents. For $p=0$, each node is connected with other local edges; if $p$ increases, the connections become increasingly disordered; for $p=1$, we have the maximum randomness and all edges are rewired [45]. For intermediate values of $p$, the network generated is properly the SWN, which is generally characterized by local interactions like the regular network, but with some path length, like a random graph [45].

\section{Application}

The present research aims at simulating a complex socio-economic-architectural adaptive system to study the temporal diffusion and the willingness of inhabitants to adopt PV systems in a specific 
case study located in the city of Turin. In this way, our hybrid agent-based model (ABM and GIS) becomes a virtual laboratory able to show empirically observed spatial and temporal patterns of PV adoption by inhabitants at the district scale. Starting from that, a policy design mix was performed to assess which kind of incentives or actions should be implemented for achieving the highest level of PV adoption. This hybrid ABM was performed in Netlogo 6.1.1. [46] with the GIS extensions. The model used the 18,182 single-family residential households in the San Salvario neighborhood $\left(2.2 \mathrm{~km}^{2}\right)$ in Turin (Italy) with a level of detail at the census block scale and a spatial resolution of $2.5 \times 2.5 \mathrm{~m}$. This neighborhood was chosen as an exemplary case study to analyze the effects of area-based policies. In this neighborhood, public administration bodies (and in particular the Energy Center, a specific office in charge for the energy policies for the city of Turin (for more details see the following link: http://www.energycenter.polito.it/) have the aim of developing in this area an exemplary eco-district for the city of Turin, where they could experiment different policies and sustainable actions that could be extended to the overall city. In particular, the single families were created based on the data provided by the Italian National Institute of Statistics (ISTAT) (accurate as of 2011) which is the most disaggregated and recent dataset containing the richest demographic characteristics of the population in Italy. The timeframe considered for the simulation is from 2011 to 2040 . The period between 2011 and 2019 was used to calibrate the attributes considered in the model, thanks to information on the adoption of residential PV provided by the Energy Services Society (GSE) Annual Report [47], whereas the period between 2019 and 2040 was used for testing policy mix solutions.

This section presents the step-by-step process of our hybrid ABM:

1. Model setup (entities, state and dynamic variables);

2. Individual family adoption calculation;

3. Policy mix framework.

\subsection{Model Implementation and Variables Setting}

For the initialization, calibration and validation of the model developed, empirical data were considered. Table 3 shows all entities considered in the model, the static and dynamic variables connected to each entity and how these variables were set, as well as the references used for identifying and setting those variables. Four types of entities were used in this model:

1. The global type refers to all entities responsible for the system-level implementation, such as electricity and policies (for the latter, we have considered both the current Italian regulatory framework and those policies designed by the authors for analyzing the possible increasing adoption of PV technology).

2. The technological type is a specific type of global entity related to the characteristics of the energy technology analyzed in our model, i.e., the PV system.

3. The environmental type collects those entities which refer to the spatial characterization of the district. In the present research, it was considered only information about the location of buildings and the census block division, since more details are not necessary for our simulation model (such as building age, rooftop surface), even if available from municipality databases. However, these entities contain real-spatial data related to family characteristics and composition. In Netlogo, the building/census block representation was performed thanks to the GIS extension based on raster data performed in QGIS 3.4.14. Each raster has specific information on the family composition, level of instruction, job employment, nationality, and property status (owners or tenants). In this way, in Netlogo, the agents with their specific characteristic contained in the raster were "sprout" from their census blocks. Sprout is a specific command in Netlogo, which mainly refers to the agents sprouting from the related environment (patches).

4. The agent type considers the single-family residential households distributed in the district. As described before, some characteristics of each family arise from the raster and represent the real-spatial distribution of specific families in the different census blocks. In this way, 
potential adopters are individual, heterogeneous agents representing the population of electricity consumers of the district.

Table 3. Entities, static and dynamic variables in the model.

\begin{tabular}{|c|c|c|c|c|c|}
\hline G/E/A/T ${ }^{1}$ & Entities & $\begin{array}{c}\text { Static } \\
\text { Variables }\end{array}$ & $\begin{array}{l}\text { Dynamic } \\
\text { Variables }\end{array}$ & Setting & Source \\
\hline G & electricity & electricity cost & \multirow{4}{*}{$\begin{array}{c}\text { electricity } \\
\text { increment cost rate }\end{array}$} & $\begin{array}{l}\text { median electricity cost in } \\
\text { Italy }\end{array}$ & Eurostat database [48] \\
\hline G & electricity & & & $-8 \%$ per year & GSE [47] \\
\hline G & policy & $\begin{array}{l}\text { subsidies per } \\
\text { kW }\end{array}$ & & $\begin{array}{l}0.5 \% \text { of investment cost } \\
\text { per } 10 \text { years } \\
\text { number of families and }\end{array}$ & $\begin{array}{c}2020 \text { Italian Budget } \\
\text { Law [49] } \\
\text { census }\end{array}$ \\
\hline E & $\begin{array}{l}\text { census } \\
\text { block }\end{array}$ & $\begin{array}{c}\text { family } \\
\text { distribution }\end{array}$ & & $\begin{array}{l}\text { their characteristics } \\
\text { (family composition, level } \\
\text { of instruction, job } \\
\text { employment, nationality, } \\
\text { and owners or tenants) }\end{array}$ & $\begin{array}{l}\text { block-municipality of } \\
\text { Turin database } \\
\text { 1:1000 (shp) + ISTAT } \\
\text { census variables at } \\
\text { census block [50] }\end{array}$ \\
\hline E & buildings & $\begin{array}{c}\text { family } \\
\text { distribution }\end{array}$ & & number of families & $\begin{array}{c}\text { building_municipality } \\
\text { of Turin database } \\
\text { 1:1000 (shp) }\end{array}$ \\
\hline A & family & $\begin{array}{l}\text { number of } \\
\text { components }\end{array}$ & & $1-6$ components & $\begin{array}{l}\text { ISTAT census variables } \\
\text { at the census block }\end{array}$ \\
\hline A & family & $\begin{array}{c}\text { energy } \\
\text { expenditure }\end{array}$ & & $\begin{array}{l}\text { median energy } \\
\text { expenditure for } n \text { of } \\
\text { components }\end{array}$ & $\begin{array}{c}\text { ISTAT energy } \\
\text { expenditure based on } \\
\text { the number of family } \\
\text { components [51] }\end{array}$ \\
\hline A & family & energy need & & $\begin{array}{c}\text { energy expenditure } \times 12 \\
\text { months/electricity cost }\end{array}$ & \\
\hline A & family & property status & & $\begin{array}{c}\mathrm{n} \text { of property and rent } \\
\text { families }\end{array}$ & $\begin{array}{l}\text { ISTAT census variables } \\
\text { at the census block }\end{array}$ \\
\hline A & family & $\begin{array}{l}\text { employment/ } \\
\text { unemployment }\end{array}$ & & $\begin{array}{l}\mathrm{n} \text { of households employed } \\
\text { and unemployed }\end{array}$ & $\begin{array}{l}\text { ISTAT census variables } \\
\text { at the census block }\end{array}$ \\
\hline A & family & nationality & & $\mathrm{n}$ of foreign citizens & $\begin{array}{l}\text { ISTAT census variables } \\
\text { at the census block }\end{array}$ \\
\hline A & family & education level & & $\begin{array}{l}\text { illiterate, literate, primary } \\
\text { school, secondary school, } \\
\text { graduation }\end{array}$ & $\begin{array}{l}\text { ISTAT census variables } \\
\text { at the census block }\end{array}$ \\
\hline A & family & status & & from 1 to 9 & $\begin{array}{c}{[21,52]-\text { Family }} \\
\text { classification for social } \\
\text { group }\end{array}$ \\
\hline A & family & income & & $\begin{array}{l}\text { normal distribution based } \\
\text { on equivalent income per } \\
\text { each class } \times \text { mean income } \\
\text { of household (standard } \\
\text { deviation based on the } \\
\text { class Gini coefficient) }\end{array}$ & $\begin{array}{c}{[21,52]-\text { Family }} \\
\text { classification for social } \\
\text { group }\end{array}$ \\
\hline A & family & & PV adoption & true or false & \\
\hline A & family & opinion & $\begin{array}{l}\text { opinion after } \\
\text { interaction }\end{array}$ & random between -1 and 1 & {$[29,53]$} \\
\hline A & family & uncertainty & $\begin{array}{l}\text { uncertainty after } \\
\text { interaction }\end{array}$ & random between 0.1 and 2 & {$[29,53]$} \\
\hline A & family & $\begin{array}{l}\text { environmental } \\
\text { awareness }\end{array}$ & & random between 0 and 1 & \\
\hline A & family & $\begin{array}{c}\text { innovation } \\
\text { level }\end{array}$ & & $1-5$ (based on the status) & {$[21,54]$} \\
\hline $\mathrm{T}$ & $\begin{array}{c}\text { PV } \\
\text { system }\end{array}$ & PV power & & $3 \mathrm{~kW}$ & \\
\hline $\mathrm{T}$ & & PV cost & & EUR 2000 per kW & \\
\hline
\end{tabular}


Table 3. Cont.

\begin{tabular}{|c|c|c|c|c|c|}
\hline $\mathrm{G} / \mathrm{E} / \mathrm{A} / \mathrm{T}^{1}$ & Entities & $\begin{array}{c}\text { Static } \\
\text { Variables }\end{array}$ & $\begin{array}{l}\text { Dynamic } \\
\text { Variables }\end{array}$ & Setting & Source \\
\hline $\mathrm{T}$ & & & $\begin{array}{c}\text { PV decreased rate } \\
\text { cost }\end{array}$ & -0.08 per year & Italian trend ${ }^{2}$ \\
\hline $\mathrm{T}$ & & & $\begin{array}{l}\text { reduction } \\
\text { efficiency }\end{array}$ & 0.6 per year & De Paoli et al. [55] \\
\hline $\mathrm{T}$ & & $\begin{array}{l}\text { maintenance } \\
\text { and operational } \\
\text { cost }(\mathrm{O} \& \mathrm{M} \\
\text { cost })\end{array}$ & & EUR $35 \times \mathrm{kWh}$ per year & Italian trend ${ }^{3}$ \\
\hline $\mathrm{T}$ & & & $\begin{array}{l}\text { O\&M increment } \\
\text { cost rate }\end{array}$ & 0.02 & Italian trend ${ }^{3}$ \\
\hline
\end{tabular}

${ }^{1} \mathrm{G}=$ global entities; $\mathrm{E}=$ environmental entities; $\mathrm{A}$ = agents; $\mathrm{T}=$ technological characteristics $(\mathrm{PV}) ;{ }^{2}$ Data provided by the practical use and tests on materials, for example: https://www.fotovoltaiconorditalia.it/idee/quanto-cala-ilrendimento-di-un-impianto-fotovoltaico-nel-tempo-e-nello-spazio; ${ }^{3}$ Data provided by the practical use and tests on materials, for example: http://www.consulente-energia.com/ao-quanto-costa-la-manutenzione-dei-pannellifotovoltaici-costo-annuo-manutenzione-ordinaria-di-un-impianto-fotovoltaico-costi-interventi-manutenzioneperiodica-fv.html.

For each agent, a set of variables was identified. The static variables are the once fixed in the entire timeframe of the simulation; the dynamic variables change every time step. For simplifying the calculation, the families created at the time 2011 do not change for the entire simulation (2011-2040) and are based on the data at the census block provided by the ISTAT for the year 2011. This choice helps us also to understand the real contribution of the policies implemented without compromising the results due to the variation of people characteristics.

At the time 0 (the year 2011 in our model), other features were provided to each family:

- Energy expenditure and energy need were defined based on the family composition. Data on the average energy expenditure for family composition at a national level were provided by ISTAT [51] and these values were simply converted into the energy need of each family as follows: energy need $=$ energy expenditure * 12 months / electricity cost;

- Status, innovation level and income are all static variables which are dependent on different combined features, such as education level, job occupation, number of components and nationality. The status classification was based on the social groups provided by ISTAT in its 2017 Annual Report [52]. The innovation level was assigned to the family based on its status class, which was, in turn, related to the diffusion of innovations classification provided by Rogers' adopters categories [54]. Finally, the income was assigned as a normal distribution value for each status class. In particular, the ISTAT analysis [52] gives information on the equivalent income and the Gini coefficient of each class. The income was thus obtained by multiplying the latter value for the mean national income (equal to EUR 29,998 in Italy in 2017) and considering, as a standard deviation, the GINI coefficient for the income of the class. The same assumptions for the definition of status, innovation level and income have been made by Bottaccioli et al. (2019) and are synthetized in Table 4;

- Environmental awareness is a static variable of the family which refers to the awareness of environmental problems. This variable represents how much a family is conscious and pro-active in adopting sustainable actions for the environment. This variable adds to the innovation and income level an alternative catalyst in the diffusion of eco-products and sustainable energy technologies (studies on this topic are, for example, [56,57]);

- Opinion and uncertainty are two static variables defined at time 0 of the model, which represent the individual family household's consideration on the PV technology. These variables, however, can change after interactive communication among the agents during the time flow. Based on the theoretical model of opinion formation and dynamic by Deffuant et al. (2002) [29] and Meadows and Cliff (2012) [53] (see Section 2), the distribution of opinions and uncertainties follow a random-flow distribution, between -1 and 1 for opinion and between 0 and 2 for uncertainty, 
respectively. In the assignment of uncertainties, it was set 0.1 as a minimum value, in order to avoid problems of values equal to 0 .

Table 4. Status, level of innovation and income with related references (adapted from Bottaccioli et al. (2019) [21]).

\begin{tabular}{|c|c|c|c|c|c|c|}
\hline ISTAT Social Group & Status & $\begin{array}{l}\text { Roger's Adopters } \\
\text { Categories }\end{array}$ & $\begin{array}{c}\text { Innovation } \\
\text { Level }\end{array}$ & $\begin{array}{c}\text { ISTAT } \\
\text { Equivalent } \\
\text { Income }\end{array}$ & $\begin{array}{l}\text { ISTAT GINI } \\
\text { Coefficient }\end{array}$ & Income \\
\hline Ruling class (RC) & 9 & $\begin{array}{l}\text { Innovators, Early } \\
\text { adopters }\end{array}$ & 5 & 1.694 & 0.283 & \multirow{9}{*}{ 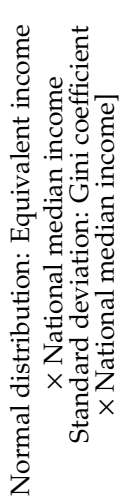 } \\
\hline Clerk household $(\mathrm{CH})$ & 8 & Early adopters & 4 & 1.323 & 0.257 & \\
\hline Young blue collars (YB) & 7 & $\begin{array}{l}\text { Early adopters, } \\
\text { Early majority }\end{array}$ & 4 & 1.135 & 0.232 & \\
\hline Silver pensioners (SP) & 6 & Early majority & 3 & 0.965 & 0.246 & \\
\hline $\begin{array}{l}\text { Low-income Italian } \\
\text { households (LI) }\end{array}$ & 5 & $\begin{array}{l}\text { Early majority, } \\
\text { Late majority }\end{array}$ & 3 & 0.934 & 0.226 & \\
\hline $\begin{array}{c}\text { Lonely old ladies and } \\
\text { young unemployed (LY) }\end{array}$ & 4 & Late majority & 3 & 0.804 & 0.324 & \\
\hline $\begin{array}{l}\text { Traditional provincial } \\
\text { households (TP) }\end{array}$ & 3 & $\begin{array}{l}\text { Late majority, } \\
\text { Laggards }\end{array}$ & 2 & 0.758 & 0.282 & \\
\hline Retired blue collars (RB) & 2 & Laggards & 2 & 0.707 & 0.290 & \\
\hline $\begin{array}{l}\text { Low income with } \\
\text { foreigners (LF) }\end{array}$ & 1 & Laggards & 1 & 0.606 & 0.283 & \\
\hline
\end{tabular}

In the initialization phase, it was defined as a fixed number of initial adopters and ecologist. Here, $1.2 \%$ of families with a status level equal to 5 in the model-the innovators-were randomly chosen as initial adopters. Once the PV adoption occured, the family in question changed its opinion and uncertainty (more or equal to 0.8 for opinion and equal to 0.1 for uncertainty, respectively). The initial percentage of adopters was proportionate to the population density of the district under analysis using the data provided by GSE [47] on the number of residential PV adoption in the metropolitan city of Turin. The adoption trend provided by GSE [47] for the year between 2011 and 2019 was also used for the calibration and validation of the model (see 4 . Results). At time 0 , about $2 \%$ of households were set as ecologists, i.e., those who have already adopted sustainable actions (such as building retrofitting, replacement windows). For those, the environmental awareness characteristic was set equal to 1 . In the same way, for each following step of the simulation, the same percentage of new ecologists was added in the model. The number of ecologists per each year was based on the data provided by ISTAT [58] on the families who invested to reduce energy consumption expenditure in Piedmont (region of the Turin city) between 2009 and 2014 .

\subsection{Individual Family Adoption Calculation}

As described in the Materials and Methods section, the mixed hybrid agent-based model presented here performs an adapted TPB [28] for developing the individual single-family households calculation for the adoption of PV systems. In particular, TPB combines SWN [25] and RA [26,27] into a real-world environment where agents are spatialized at a census block scale thanks to the integration into the Netlogo software of some GIS maps, which contains a set of information about families' characteristics.

In this section, a detailed explanation of the different components ( $a t t, s n, p b c)$ of TPB, used in the present analysis for defining the intention and the behavior of the single-families in adopting PV system, is given. In particular, Figure 3 shows, for illustrative purposes, exemplary questions and reasonings of individuals in the formation of the intention and actual control in the present analysis and according to TPB. For the different TPB components, equal weights were assigned due to the lack of information caused by the inability to conduct a specific questionnaire in the neighborhood for the COVID-19 spread in the city of Turin. 


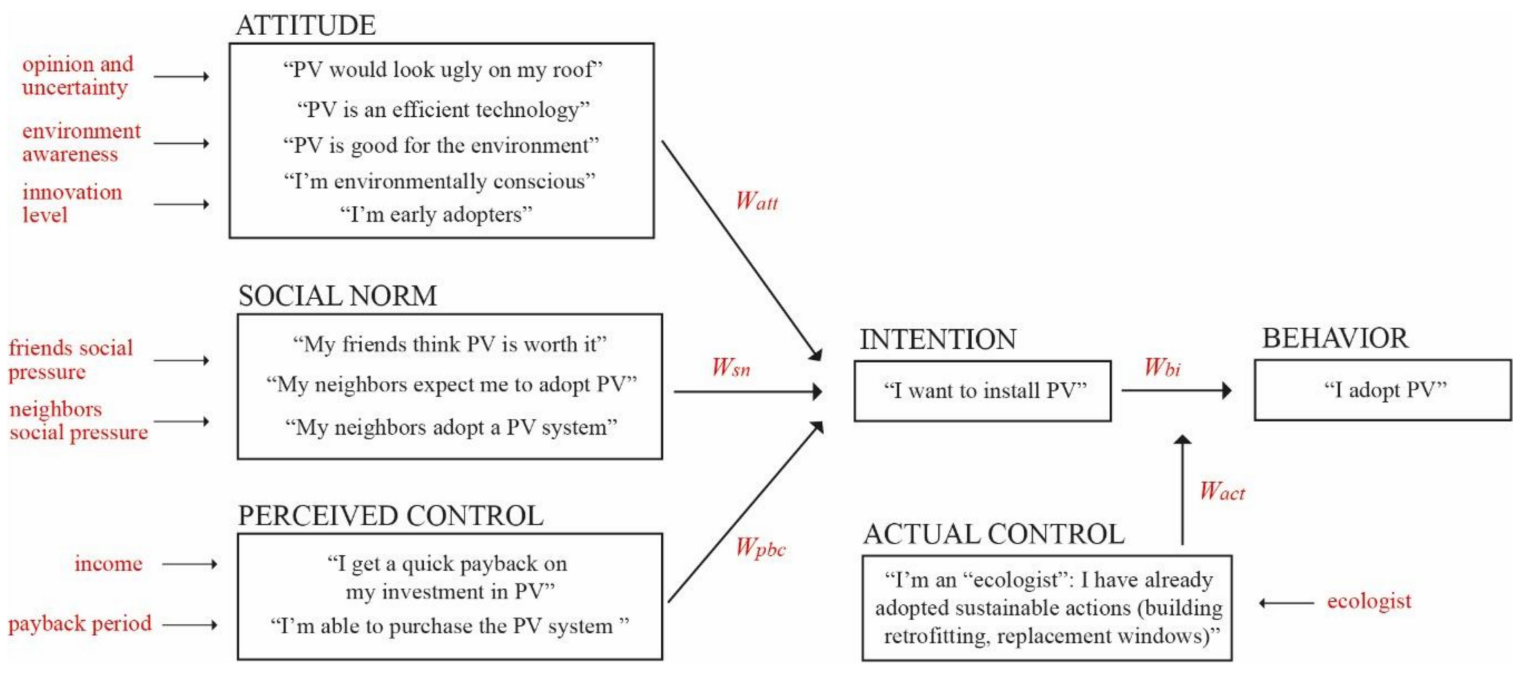

Figure 3. Components of the behavior for PV adoption (adapted from Ajzen (2002) and Robinson et al. (2013)).

\subsubsection{Attitude Toward the Behavior (att)}

Three different beliefs were considered for the creation of the agents' att, based also on the literature review of ABM applications for the adoption of PV (as reported in Figure 4):

- Opinion (opi) is strictly related to the PV technology and, in particular, to the consideration that each agent has on the technology in itself (such "PV would look ugly on my roof?", "PV is an efficient technology?") (see for example [21,24]). The definition of agents' opinions, as mentioned in the Methods, follow the RA theory. Every year, agents create their own networks, following the SWN theory (see Section 2.2.3), as shown in Figure 4. These networks, then, change every 5 years, simulating the variation of relations among people during the years. The assignment of the opinion (as for the uncertainty) did not depend on one or more background factors of the agents, but simply it was assigned to each agent as a random opinion between -1 and 1 (as for uncertainty between 0.1 and 2, where the minimum uncertainty 0 was excluded for avoiding problems in the calculation). As mentioned in the previous section, 1.2\% families at time 0 have already adopted the PV; they represented the innovators (or extremists in the model) and, their opinion and uncertainty were set as follows: $x>=0.8$ and $u=0.1$. For the final formulation of the agent's attitude, the opinion should be standardized. In the present analysis, an interval standardization was performed: $\left(x-x_{\min }\right) /\left(x_{\max }-x_{\min } \cdot\right)$

- Environmental awareness (aw env $)$ is a constant awareness between 0 and 1 (see, for example, [22]), where 0 represents low awareness on environmental problems, whereas 1 is high interest in the environmental issue. As for the opinion and uncertainty, also the environmental awareness was defined with a random distribution, without any dependence on other characteristics of the agent. This variable can change only when an agent was selected as a new ecologist over the lifespan.

- Innovation level (inn) is the last component of the individual attitude of an agent and represents the propensity toward an innovation. This static variable depends on many characteristics, such as lifestyle, habits and personality, and for that reason, in our model, it was assigned to an agent based on their social role [21]. The innovation values vary between 1 to 5, where 1 means a low level of innovation, whereas 5 represents high innovativeness of the agent. For the innovation level, it is necessary to perform the interval standardization before the final calculation of the attitude. 

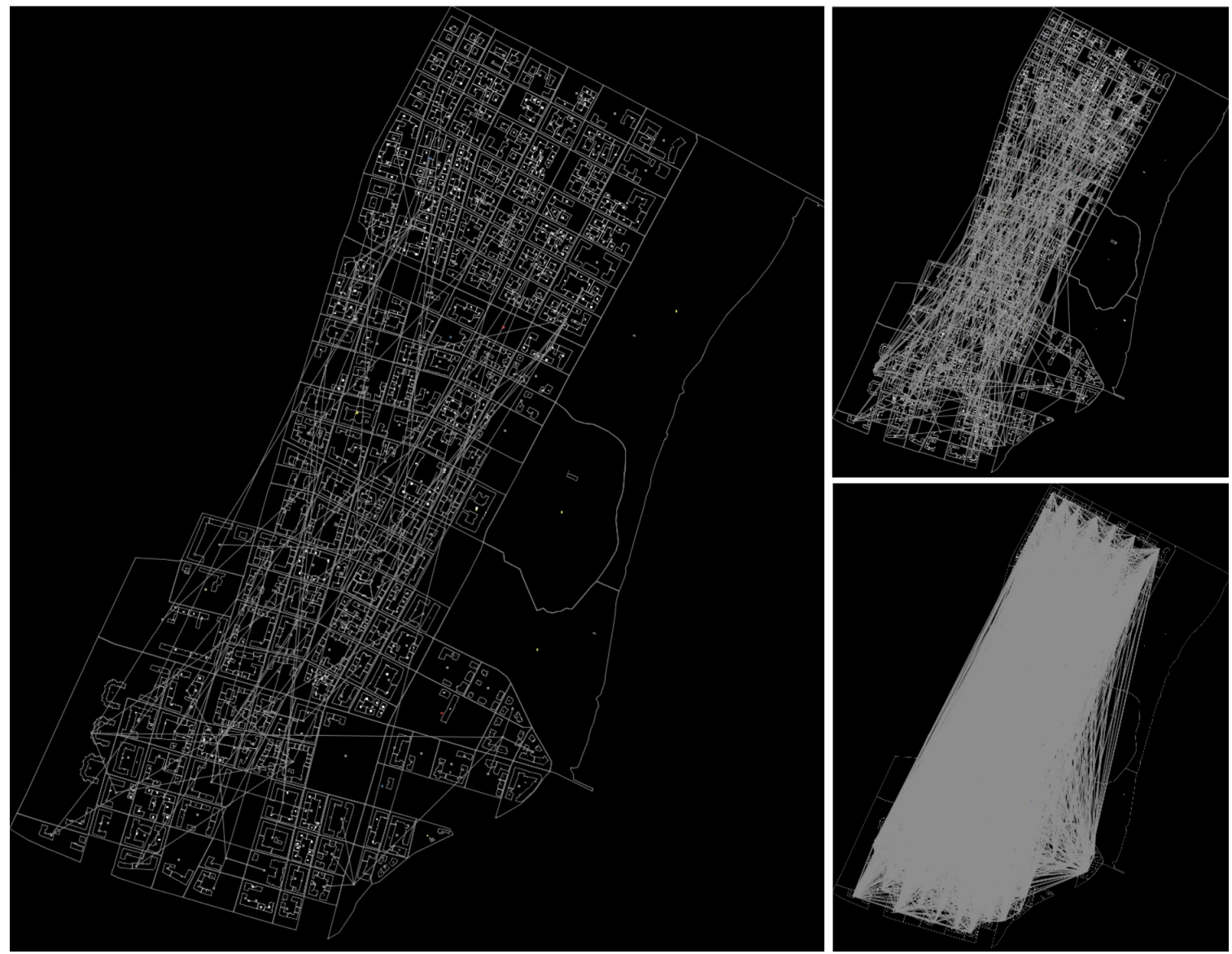

Figure 4. Dynamic network formation of the agents in the neighborhood following SWN.

Opinion (opi) and environmental awareness (awenv) are very complex beliefs which are commonly based on a variety of agent's background factors and their interrelations, such as personality, experience, education, knowledge and/or feelings. The approach adopted in the present research is, thus, certainly simplified. In fact, opinion (opi) and environmental awareness (awenv) are only assigned through a random distribution, and these beliefs can be changed due to the interactions with other agents. However, because of the complexity in modeling those beliefs, a simplification of the reality is needed, in particular when no data or empirical analyses show how to detail them. For the innovation level (inn), which is more consolidated in literature, the present research tried to combine the different background factors that influence the formation of the innovation level, such as lifestyle, habits and personality, following Roger's adopters categories [54] (see Table 4).

Agent's attitude toward the behavior was performed as follow:

$$
a t t=o p i_{s t d} * W_{s t z}+a w_{e n v} * W_{e n v}+i n n_{s t d} * W_{i n n}
$$

where $W_{s t z}, W_{\text {env }}$ and $W_{i n n}$ represent the different weights assigned by individuals to each component in the construction of their personal att. For lack of specific data and surveys on that topic, the three components all have the same weight equal to 0.33 .

\subsubsection{Subjective Norm (sn)}

For the calculation of the subjective norm (second element of the TPB theory), two levels of pressures on the behavior are considered: the social pressures of those in the same network (considered 
as «friends») and the pressures generated by the common feelings in the entire neighborhood. The result is a weighting sum of these two pressures as below:

$$
s n_{i}=s p_{\text {link }} * W_{\text {splink }}+s p_{\text {district }} * W_{\text {spdistrict }}
$$

where the weigh $W_{\text {splink }}$ is defined in the simulation stronger than $W_{\text {spdistrict }}$, assuming that friends have a predominant role in influencing behavior (respectively, 0.7 and 0.3 ) and $s p_{\text {link }}$ and $s p_{\text {district }}$ are both calculated based on the mean values of attitude in the network and in the neighborhood, in the following way:

$$
s p_{i j}=a t t_{i} *\left(1-w_{i j^{*}}\left(a t t_{i}-a t t_{j^{*}}\right)\right)
$$

where $s p_{i j}$ is the social pressure exerted on agent $i$ by the agent $j^{*}$, that is a fictitious agent described by the mean of the attitudines of the agents in the network (for $s p_{\text {link }}$ ) or in the neighborhood (for $s p_{\text {district }}$ ), and $w_{i j^{*}}$ is the strength of the influence exerted by agent $j$ over agent $i$ :

$$
w_{i j^{*}}=\frac{\frac{u n c_{i}}{u n c_{j^{*}}}-0.05}{20-0.05}
$$

where 20 and 0.05 are, respectively, the maximum and minimum value for establishing the influence rate between 0 and 1 .

\subsubsection{Perceived Behavior Control}

The perceived behavior control (the third component of the TPB) was calculated in the present research combining a rapid payback period quantification and a comparison of the income of the agent with the minimum and maximum income in the neighborhood, as follows:

$$
p b c_{i}=p f_{i} * W_{p f, k^{i}}+i f_{i} * W_{i f, k^{i}}
$$

where the weights $\left(W_{p f, k^{i}}\right.$ and $\left.W_{i f, k^{i}}\right)$ are both equal to $0.5, p f_{i}$ is the payback of the agent $i$ and $i f_{i}$ is the income of agent $i$ compared with the mean income of all agents in the model.

The $i f_{i}$ factor represents the capability of the household to purchase the investment, considering his/her income condition compared to the one in the neighborhood. We strongly simplify the calculation of this factor, considering the most real and easy way of people reasoning, in contrast with the calculation provided by Schiera et al. (2019) [21] and Zhao et al. (2011) [23]. These two publications consider the level of income per capita of a household as the average income value of the adopters in the neighborhood according to an exponential relation. We consider that the level of information of people on the socio-economic status of the adopters is low and, as a consequence, the perceived control is more based on their general income situation compared with the condition in the neighborhood. In our case, $i f_{i}$ is simply calculated as follows:

$$
i f_{i}=\frac{\text { income }_{i}-\text { minincome }_{t}}{\text { maxincome }_{t}-\text { minincome }_{t}}
$$

The $p f_{i}$ factor was based on an interval standardization of the payback period (15) calculated by the agent to know the time required to recoup the investment on the PV:

$$
p f_{i}=\frac{p p-20}{1-20}
$$

where 20 is the minimum value of the standardization corresponding to the maximum lifetime of the panel.

To obtain this payback period, a dynamic discounted cash flow (DCF) analysis was performed. We call the DCF performed as dynamic because each year of the simulation, some variables change their 
values. These variations can be related to market condition, such as the PV variation cost, the incentives on the investment and the increasing electricity cost over the time, or to the reduction efficiency of the panel and their related operational and maintaining costs. These changes during the timeframe had both a positive and negative effect on the decision to install the PV system. Considering, for example, that the cost of the panel decreased by 15.5\% from 2002 to 2016, in our simulation it was assumed a constant yearly reduction in the price equal to $8 \%$, similarly to Schiera et al. (2019) [21]. On the contrary, it was assumed that the cost of electricity will increase with a rate of $2 \%$ each year, based on GSE [47] estimation. Details on the attributes variation in the model are reported in the column called Dynamic variables contained in Table 3.

For the payback calculation, each year the agent calculates the net present value (16) in order to report all values to the evaluation time and compared to the investment cost, as below:

$$
\begin{gathered}
n p v=-I+\sum_{y=0}^{n} \frac{R(y)}{(1+r)^{y}} \\
n p v \geq 0 \rightarrow y=p p
\end{gathered}
$$

where $r$ is the discount rate $(r=0.8 \%$, i.e., mean discount rate calculated from 2011 to 2019 (for details see the following link: https://www.miolegale.it/utilita/tasso-interesse-legale/), $n$ is the last year of the $n p v$ calculation, which corresponds to the maximum PV lifetime (20 years), $y$ corresponds to the time, $R(y)$ is the net cash flow (i.e., cash inflow minus cash outflow, at time y). The net cash flow is initialized equal to the investment $I$ (with a minus sign). The year $(y)$ when the $n p v \geq 0$ corresponds to the payback period $(p p)$.

The investment $I$ takes into account when the agent starts to think about the installation and, so, on the variation $\left(t_{P V}\right)$ over the time of the PV cost in the market:

$$
I(y)=C_{P V} *\left(1+t_{P V}\right)^{y}
$$

$R(y)$ is calculated as the difference between revenues and costs over time:

$$
R(y)=-O \& M(y)+R_{t a x}(y)+R_{t}(y)
$$

$O \& M(y)$ corresponds to the yearly maintaining and operational costs. $R_{t a x}(y)$ are the annual financial reliefs spread over 10 years provided by the Italian government for the purchase of the PV. $R_{t}(y)$ are the total revenues produced by the PV installation. Their specific calculations are reported in the following equations:

$$
O \& M(y)=C_{O \& M} *\left(1+t_{O \& M}\right)^{y}
$$

where $C_{O \& M}$ is a fixed yearly cost (equal to EUR 105/y) per $\mathrm{kW}$ installed, whose value increases every year by an incremental quantity equal to $2 \%$.

$$
\begin{gathered}
R_{\text {tax }}(y)=I(y) / 10 \\
R_{t}(y)=R_{P V}(y)-R_{\text {grid }}(y) \\
R_{P V}(y)=\left(E n_{\text {comp }}-\left(E_{P V \text { output }}(y) *\left(1-r_{\text {eff }}\right)^{y}\right)\right) *\left(C_{E_{\text {grid }}} *\left(1+t_{\text {egrid }}\right)^{y}\right) \\
R_{\text {grid }}(y)=\left(E n_{\text {comp }} *\left(C_{\text {Egrid }} *\left(1+t_{\text {egrid }}\right)^{y}\right)\right)
\end{gathered}
$$

where $E n_{\text {comp }}$ is the energy need required by each family based on the number of components and this value is calculated as follows: $E n_{\text {comp }}=E_{\text {exp }} * 12 / C_{\text {Egrid }}$. $E_{\text {exp }}$ corresponding to the median monthly energy expenditure per the number of components based on ISTAT statistics of 2018 on family expenses [51]. 
$E_{P \text { Voutput }}$ is the energy produced by the panel, taking into account the panel efficiency $\varepsilon$ (irradiance, exposition, etc.) fixed in the neighborhood equal to 0.6. $r_{e f f}$ is the reduction coefficient of the panel during its lifespan $\left(0.8 \%\right.$ each year $\left.{ }^{5}\right)$.

$C_{E \text { grid }}$ is a constant price of the electricity that considers also the service costs; it is fixed equal to 0.23 , while its variation over time is given by $t_{\text {egrid }}$ with an increasing rate of $2 \%$ each year, based on GSE [47] estimation.

\subsubsection{Actual Control}

The actual control act is the last component required for the calculation of the behavior (see Figures 1 and 4). In TPB, act is often considered equal to the $p b c$, when information is limited because $p b c$ is considered as veridical. However, act is strongly based on past experiences and failures, that could be quite easily measured in the context of green products adoption. For that reason, the present research has considered both the case of $a c t$ equal to $p b c$ and equal to environmental awareness $\left(a w_{e n v}\right)$. The latter, as mentioned before, contains the information about who has already adopted sustainable actions (such as building retrofitting, replacement windows), thus perfectly representing a past behavior in line with the PV adoption. Experiments on these two act calculations show that the second approach represents well the real adoption conditions in the neighborhood under analysis.

\subsection{Policy Design}

The main objective of this research is to provide a virtual laboratory for testing alternative policy scenarios, thus supporting policymakers in the definition of effective actions at the local scale. Four different policies are tested in the model:

- Scenario 0 represents the state-of-the-art of the actual policy in the Italian context, which consists of the $50 \%$ tax relief on the investment cost for the purchase of PVs, deferred for ten years;

- Scenario 1 considers a different subsidies policy for low-income and high-income classes. Low-income people receive a subsidy equal to the $70 \%$ of the investment cost in ten years. For high-income people, two alternatives are tested: the first alternative considers no subsidies and the second one considers a subsidy equal to the $30 \%$ of the initial investment;

- Scenario 2 introduces to the actual Italian policy, a discount voucher proposed by PV sellers:; this discount may be obtained by families if in their network there is at least one adopter. Different levels of discount were tested in the model $(10 \%, 20 \%$ and $50 \%)$;

- Scenario 3 provides for an information campaign on environmental issues in order to increase the population awareness over this topic. A medium and a high information diffusion are tested, as a percentage increase in the level of environmental awareness of the individual, equal to 0.5 and 1.0, respectively;

- Scenario 4 considers the development of an information campaign for increasing population awareness over the advantages of adopting the PV system. Additionally, in this case, two levels of information diffusion (medium and high) are considered, equal to 0.5 and 1.0, respectively.

\section{Results}

The model was calibrated based on the data of PV diffusion and trends in Italy and the metropolitan city of Turin, contained in the GSE report [47] (Table 5). These data are reported for the San Salvario neighborhood using a simple density proportion and homogeneous distribution of the values in the 8 years considered (last row of Table 5). 
Table 5. PV diffusion in Italy and the metropolitan city of Turin provided by GSE [47], used to identify the number of adoptions in the San Salvario neighborhood.

\begin{tabular}{llllllllll}
\hline & $\mathbf{2 0 1 1}$ & $\mathbf{2 0 1 2}$ & $\mathbf{2 0 1 3}$ & $\mathbf{2 0 1 4}$ & $\mathbf{2 0 1 5}$ & $\mathbf{2 0 1 6}$ & $\mathbf{2 0 1 7}$ & $\mathbf{2 0 1 8}$ & $\mathbf{2 0 1 9}$ \\
\hline PV adoption in Italy & 160,963 & 335,358 & 485,406 & 596,355 & 648,196 & 687,759 & 732,053 & 774,014 & 822,301 \\
$\begin{array}{l}\text { PV adoption in the } \\
\text { Metropolitan City Turin }\end{array}$ & 4293 & 8762 & 12,529 & 15,280 & 16,556 & 17,526 & 18,611 & 19,636 & 20,813 \\
\% residential & & & & & $81 \%$ & & & & \\
$\begin{array}{l}\text { \% PV in San Salvario } \\
\text { \% PV in San }\end{array}$ & 137 & 280 & 400 & 488 & 528 & 559 & 594 & 627 & 664 \\
$\begin{array}{l}\text { Salvario-omogeneous } \\
\text { distribution per year }\end{array}$ & 137 & 203 & 269 & 335 & 401 & 466 & 532 & 598 & 664 \\
\hline
\end{tabular}

Some parameters sweeping on attributes values were conducted to verify the robustness of the simulation model (such as on the type of interactions, $\mu$, number of turtles in the network, PV installation power, and behavior threshold), but also on the calculation of the attribute (such as for the income attribute $i f_{i}$ and the actual control $a c t$ ). These analyses were conducted using the BehaviorSpace (for details see the following link: https://ccl.northwestern.edu/netlogo/docs/behaviorspace.html), a tool integrated in NetLogo, which performs experiments on the model.

Figure 5 reports the results of the calibration phase, showing the comparison of the real data and a representative set of simulations conducted. As can be seen, only slight variations are visible between the two, but the model generally describes well the real condition of diffusion in the neighborhood.

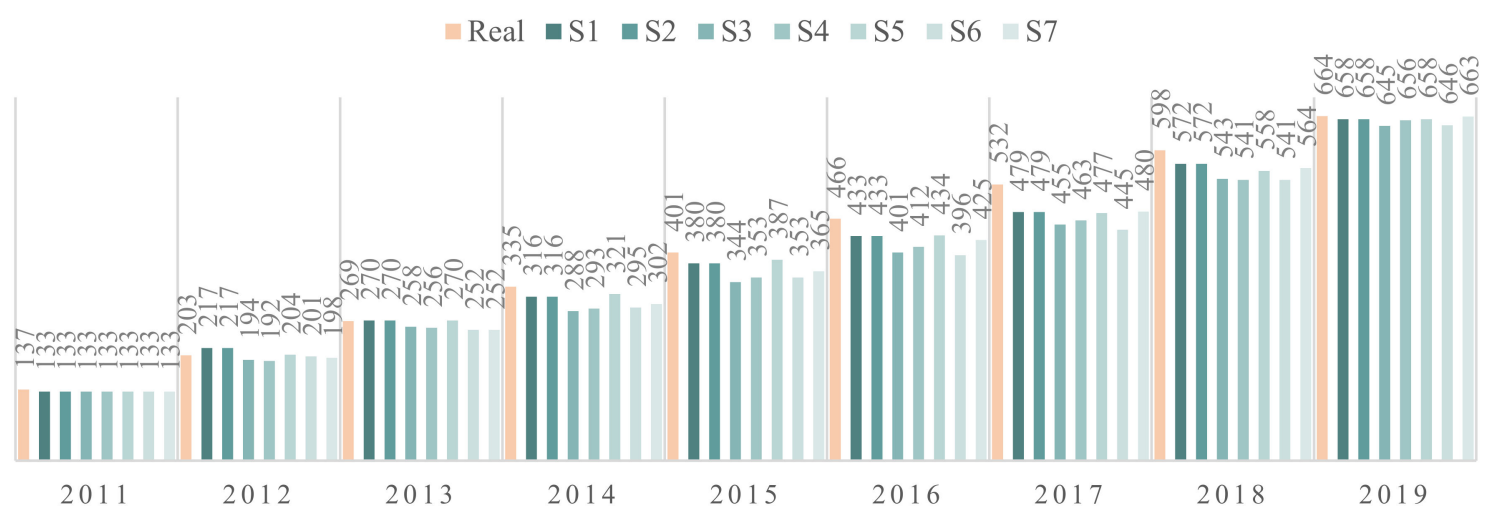

Figure 5. Comparison between real-world data of PV adoptions (pink) and seven exemplary simulation results (blue).

The differences between the six simulations reported are due to some variations in the family compositions and the random assignment of some values. Table 6 shows the aspects that contribute to these variations in the results.

To analyze the quality of the model implemented, some experiments were also conducted considering extreme conditions of population characteristics (Figure 6). In the population with very low income (in Figure 6 "lowI") in the entire neighborhood (and all the other characteristics fixed as previous simulations), no one decided to adopt the system. In the population with average income (in Figure 6 "averageI"), the number of adoptions was lower than that of the real spatial model implemented (e.g., in 2019 the adopters were less than 400). At the beginning of the simulation runs, for the population with high income (in Figure 6 "highI"), the trend of adoptions was similar to the model implemented, but at the end of the simulations, about 900 people adopted PV systems. When extreme values of opinion and uncertainty of the agents were simulated, the results were more similar to that of the model implemented: for high uncertainty and low opinion (in Figure 6 "lowO-highU"), it was necessary to wait for a longer timeframe to achieve the same results (e.g., in 2015 only about 180 people had already adopted the technology, but in 2019 about 600 people decided to adopt it). For low uncertainty and high opinion (in Figure 6 "highO-lowU"), at the beginning, 
the trend was very similar, but at the end, the adoptions started to decrease. This can be explained by the fact that a variety in opinion and uncertainty (unlike extreme positions) is more useful in diffusion technology because, due to the interaction, people can change their positions on a specific topic.

Table 6. Variables that can modify the results in each simulation run.

\begin{tabular}{|c|c|c|}
\hline Static Variables & Dynamic Variables & Description \\
\hline Property status & & $\begin{array}{l}\text { After the formation of the families with all their characteristics } \\
\text { in the neighborhood, the model excludes all families with a } \\
\text { rental contract, because these families cannot decide on } \\
\text { adoption. This means that for every simulation run, } \\
\text { the families excluded can, to some extent, change the } \\
\text { configuration of the possible adopters. }\end{array}$ \\
\hline \multirow{6}{*}{$\begin{array}{l}\text { Opinion } \\
\text { and uncertainty } \\
\text { Environmental } \\
\text { awareness }\end{array}$} & & $\begin{array}{l}\text { These two variables are assigned with a random distribution } \\
\text { whenever the model starts to run the simulation. }\end{array}$ \\
\hline & & $\begin{array}{l}\text { Same as before, the number of ecologists at the beginning of } \\
\text { the simulation, and every year, was the same. }\end{array}$ \\
\hline & $\begin{array}{l}\text { Attitude toward } \\
\text { the behavior }\end{array}$ & $\begin{array}{l}\text { Since this attribute depends on opinion and environmental } \\
\text { awareness, the initial configuration of those variables affects } \\
\text { the results of the attitude toward the behavior. }\end{array}$ \\
\hline & Social norm & $\begin{array}{l}\text { Since this attribute depends on opinion, environmental } \\
\text { awareness and attitude toward the behavior, the initial } \\
\text { configuration of those variables and attributes affects the } \\
\text { results of the social norm. }\end{array}$ \\
\hline & & $\begin{array}{l}\text { Interactions among agents followed SWN, choosing randomly } \\
\text { a fixed number of agents (e.g., } 6 \text { ) inside and outside the radius } \\
\text { selected }(20 \mathrm{~m}) \text {. The model implemented asked agents to } \\
\text { change their network every } 5 \text { years. This does not mean that }\end{array}$ \\
\hline & Interactions network & $\begin{array}{l}\text { an agent changes his/her opinion, attitude and social norm } \\
\text { after five years; in fact, during this timeframe, agents are } \\
\text { influenced also by the neighborhood as a whole, and this } \\
\text { influence can also change opinion, attitude and norm in } \\
\text { the network. }\end{array}$ \\
\hline
\end{tabular}

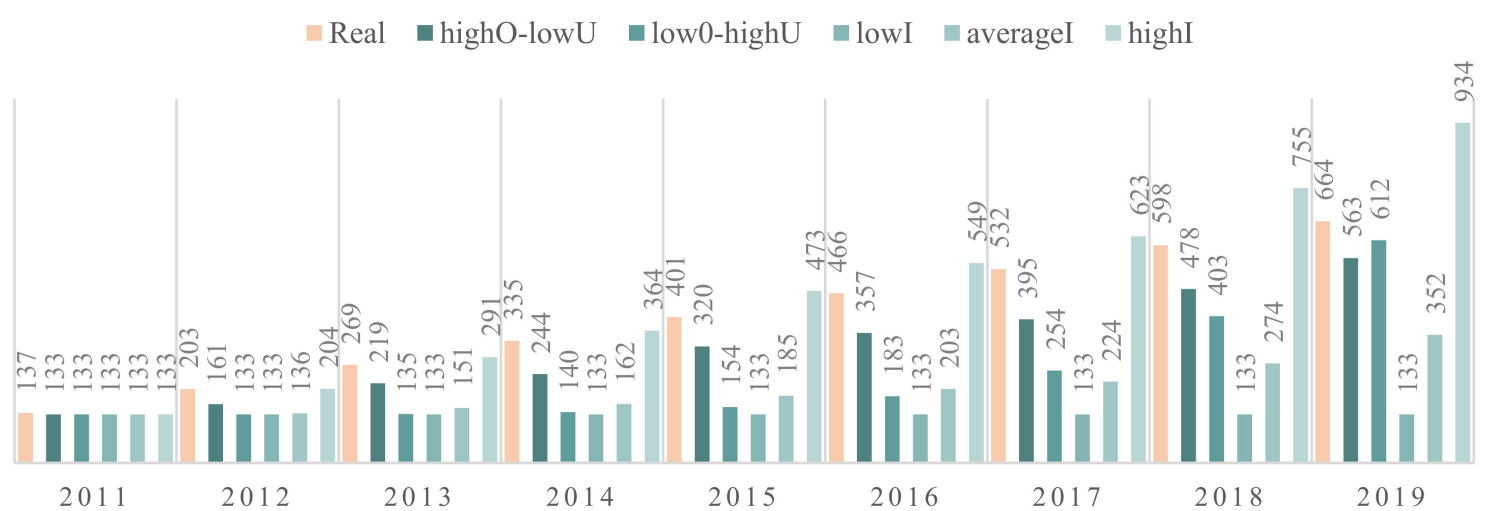

Figure 6. Experiments on the quality of the model with extreme population conditions.

Next, the alternative policy scenarios were tested to verify their efficiency, see Figure 7, Figure 8, Figure 9, Figure 10. All policies were compared to the results of current law simulations (Scenario 0 ): the $\mathrm{x}$-axis shows the number of people who adopt the PV and the y-axis shows the years of the performed simulation. In particular, the number of adopters per year was based on the mean value obtained from 20 simulation runs developed for each scenario. 
$\square$ Scenario $0 \square$ Scenario 1 (high-income 0 low-income 0.7) $\square$ Scenario 1 (high-income 0.3 low-income 0.7)

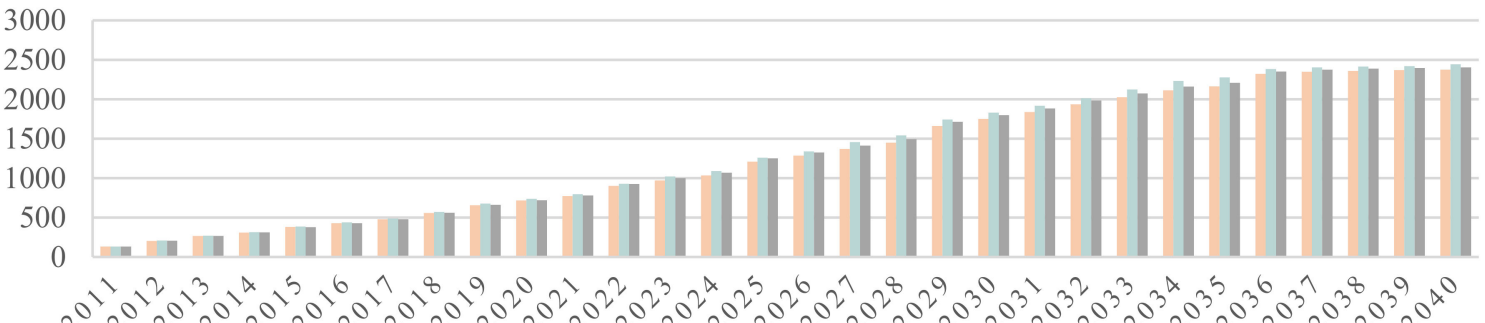

Figure 7. Comparison between Scenario 0 and Scenario 1.

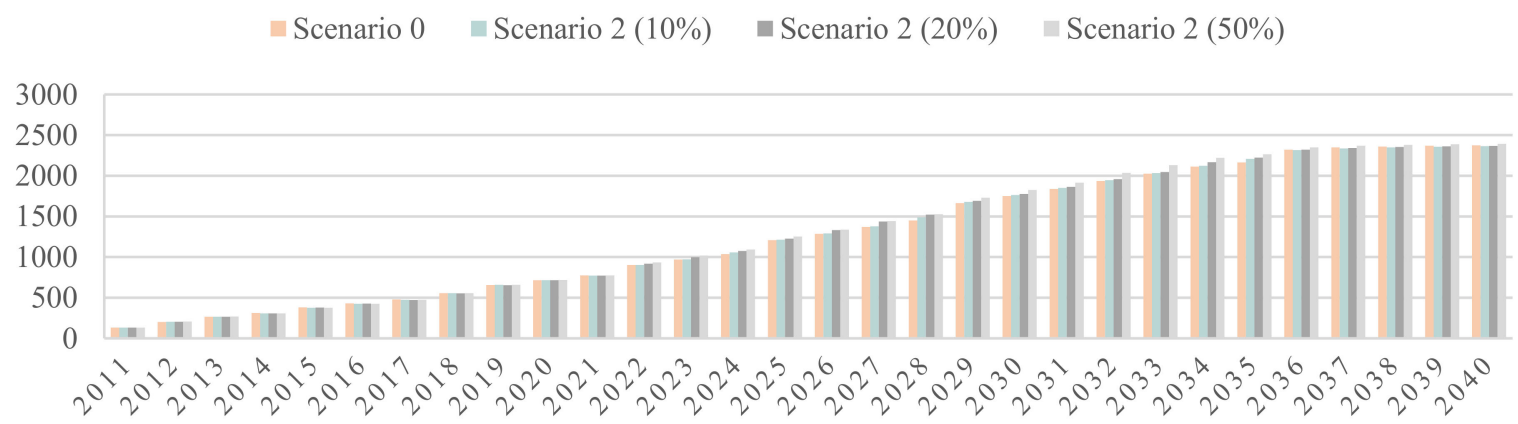

Figure 8. Comparison between Scenario 0 and Scenario 2.

$\square$ Scenario $0 \quad$ Scenario $3(0.5) \quad$ Scenario $3(1.0)$

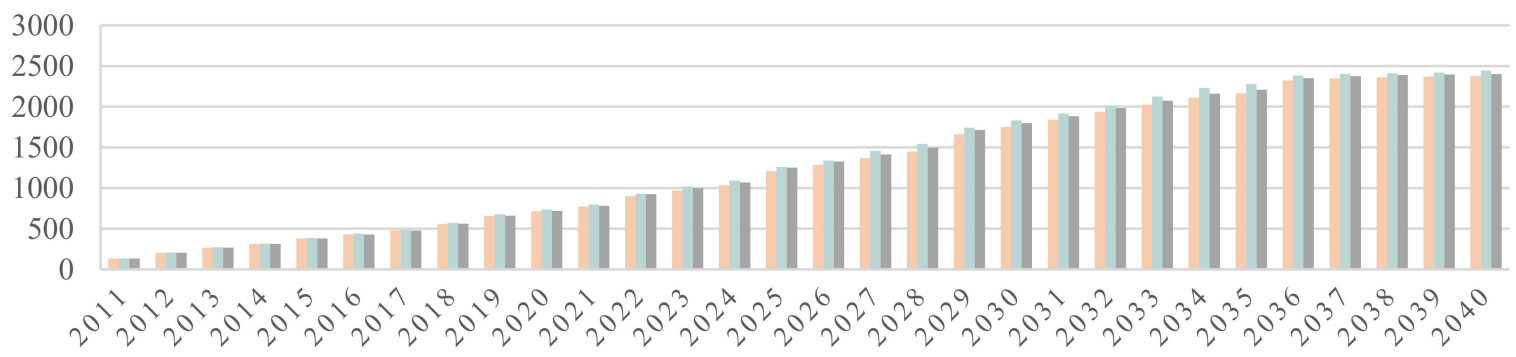

Figure 9. Comparison between Scenario 0 and Scenario 3.

$\square$ Scenario $0 \quad \square$ Scenario $4(0.5) \quad \square$ Scenario $4(1.0)$

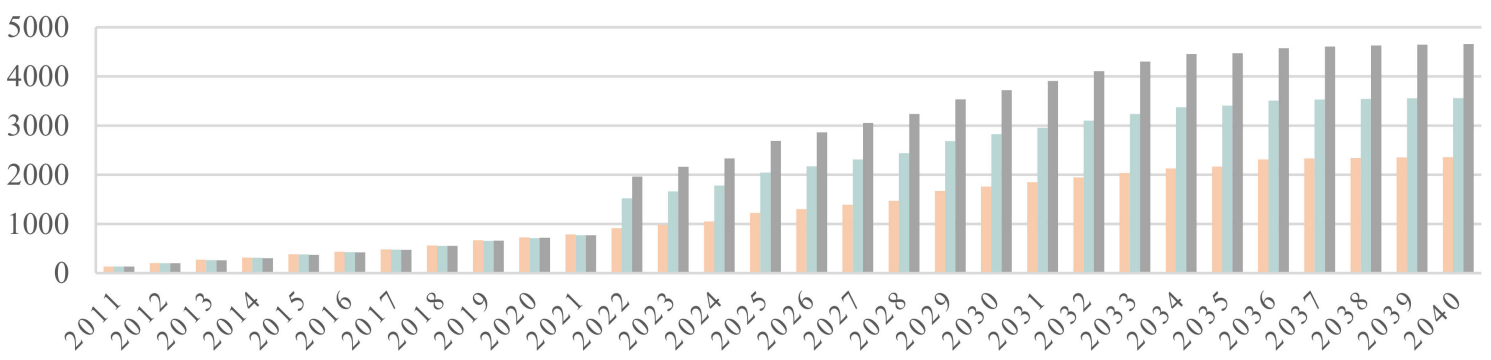

Figure 10. Comparison between Scenario 0 and Scenario 4.

The results of the policy simulations generally show that economic policies did not give a real and effective contribution. Figure 7 shows the policies designed for low-income people. Figure 8 highlights the contribution of voucher policy with different degrees of discount. None of these policies contributed to an increase in family adoption. Although these results may seem strange at first, they can be explained with two reasons: firstly, non-economic motivations are fundamental in individuals' decision-making processes (e.g., environmental awareness or innovation level), secondly, economic 
reasons are often affected by knowledge and information on the technology under analysis. This effect is apparent both in empirical agent-based model applications in innovation diffusion, such as [59-61], and, more in general, in individuals' attitudes and behaviors research, such as [62,63].

For these reasons, we also tested other policies that consider other motivations for the efficiency of sustainable actions and strategies. Concerning Scenario 3, as shown Figure 9, information campaigns on environmental issues were not efficient in the diffusion of PV systems. However, the increase in technological awareness (Figure 10) was more suitable for that purpose, demonstrating the role of communication and information of people with respect to technological benefits and advantages. In particular, the awareness of the PV advantages was the main catalyst in the adoption of PV in the San Salvario neighborhood, demonstrating the role of information in the diffusion of green products.

Figure 11 shows the variation of quantity in the adoption of PV over time for Scenario 0: (a) 2011, (b) 2019, (c) 2040. These distributions result from the calculation of the mean of adoptions in each single block from ten simulations performed with the same policy scenario (Scenario 0). The figure exemplifies the combined use of ABM and GIS for a dynamic simulation of the process under investigation. Analogously, similar maps have been produced for the other scenarios considered in the present study that have been useful for visualizing in a clear and easy way the results of the model. From the data of the maps, it is apparent that the difference in the spatial distribution of adopters is very small. The south-west portion remains the area with the greatest adoptions over the years, with an increase from less than 10 adopters in 2011 to more than 70 in 2040. The increase in adoptions in the other blocks of the neighborhood is not strongly evident in specific areas, but quite well distributed. However, the north-east portion mantains the higher number of adopters over the years, unlike the middle area. Integrated analysis on the people's characteristics and their spatial distribution would help us to establish the reasons of these results, as well as to develop specific policy mix in the neighborhood. 


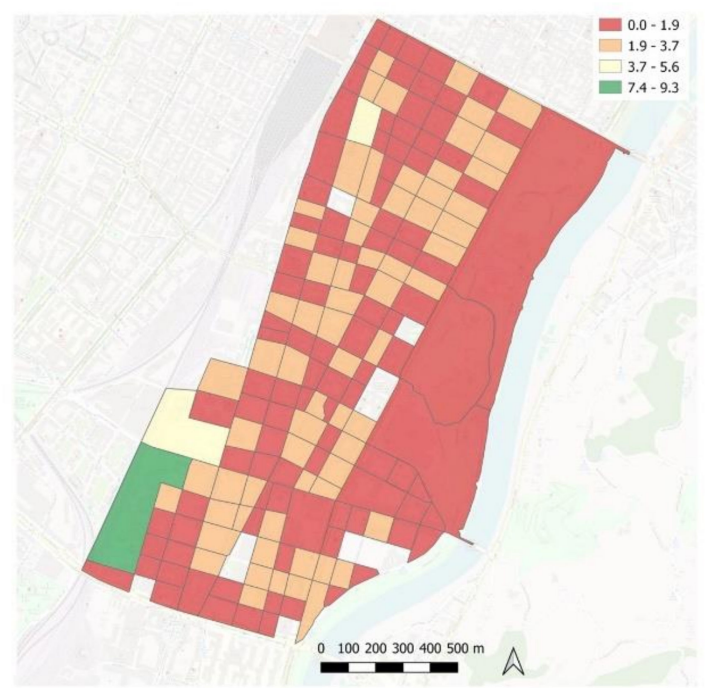

(a)

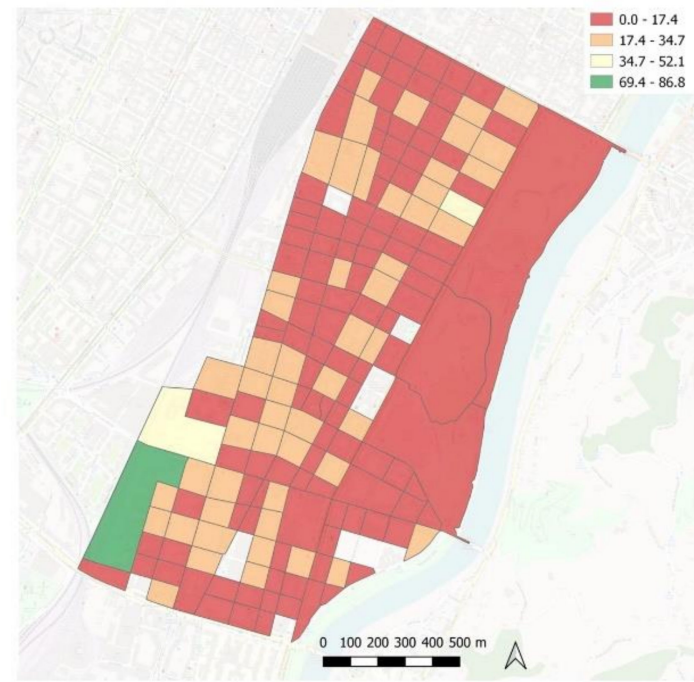

(c)

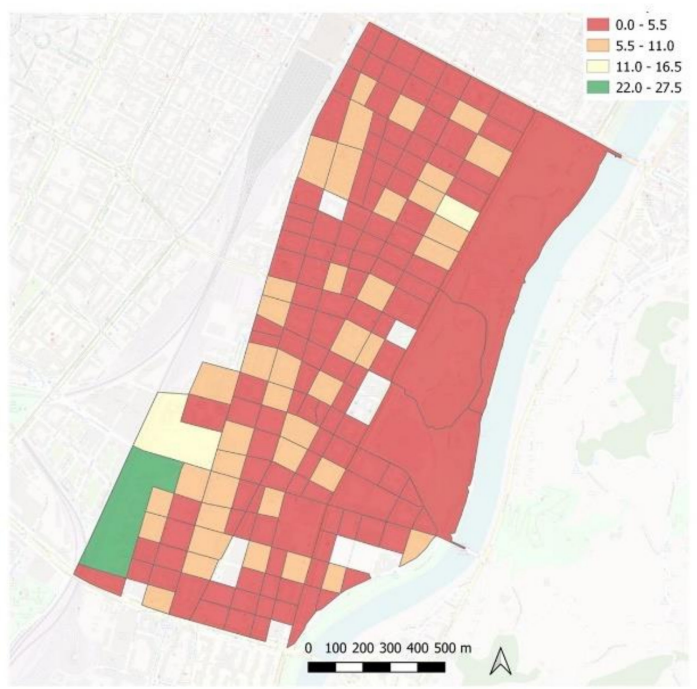

(b)

Figure 11. Variation of quantity in the adoption of PV over time for Scenario 0: (a) 2011, (b) 2019, (c) 2040 .

\section{Discussion and Conclusions}

The present research investigates the potentialities of a mixed-method approach, which combines ABM with GIS in the definition of strategic policies for the diffusion of PV systems in a real case study of the San Salvario neighborhood in the city of Turin (Italy). The study demonstrates the "exploratory simulation" [12] capability of ABM in studying complex systems and in supporting the decision-making process, becoming a sort of virtual laboratory [13] in a vision of sustainable development of our cities.

Some innovations can be detected in the present contribution. Firstly, it represents the first European attempt to simulate solar photovoltaic adoption with a level of detail of individual characteristics at the census block scale. The only examples in literature are in Austin (Texas) [26] and in the Gangnam district, Seoul (South Korea) [20]. This detailed analysis of individual decisions allows DMs to study the effects of policies based on the real conditions of the population and the place under analysis. Secondly, the model tests the efficiency of information programs provided by the municipality on environmental and technological awareness of citizens. The other contributions on this topic only explore in different ways the role of economic policies in increasing the diffusion of this 
technology. Our findings indicate that information campaigns, in particular those on the advantages of PV adoption, are the main catalyst in the diffusion of the technology-more so than economic or fiscal incentives. Thirdly, the present analysis tests the formation of actual control (act) in different ways, showing how past experiences and behaviors are better at describing the real contribution of this component of the TPB in the context under analysis than the repetition of perceived behavior control $(p b c)$.

Future research will regard a more in-depth explanation of the results obtained: in this work, we focused only on the final results of policy implications without considering the characteristics of adopters (e.g., income level, level of education, spatial distribution in the neighborhood) and the mean level of attitude, social norm and perceived behavior control. All these insights are strongly relevant for the design of effective policies, including the real context of San Salvario. Individuals with favorable attitudes are those first convinced to adopt PV. Building on this, we will be able to test a policy mix based on the case study under analysis, and its specificity and contextual factors.

Another perspective of the research will be the comparison of the results based on proximity random interactions, and people characteristics and status. The present model only considered interactions among agents in spatial terms without connecting them to other aspects, such as a similar education level, income or status.

Moreover, due to the COVID-19 situation, some data used for the implementation of the model were simply based on statistical data (e.g., the number of ecologists) which refer to the entire region of Piedmont and are not site-specific or, in other cases, assigned randomly (e.g., opinion and uncertainty). As a result of this, the next steps of the research will consider the construction and conduction of a specific questionnaire in the neighborhood for collecting all these data, thus improving not only the quality of the model performed but also identifying what is relevant and what is not in an individuals' decision-making process, in particular in the context of San Salvario and for the adoption of new sustainable technology such as the PV systems. In this way, it will also be possible to give more reliability to the present simulation, taking into account the attitudes and reactions of citizens where green products and practices are concerned.

Some reasonings in TPB can be criticized because people may often find them hard to grasp (e.g., fluctuation of price along the time or the rational calculation of payback period). However, other aspects such as social norm considerations, opinion and uncertainty, and environmental awareness are able to capture more intangible and extra-economic reasons in the human decision-making process.

The present application shows the ability of the integrated and adapted TPB in representing the historical trend of PV adoption in the metropolitan city of Turin. This proves that it can be used as a virtual laboratory to test the efficacy of policy mix in a given neighborhood. However, the main effort in future research development will regard the comparison of TPB with other implementation models. This is particularly relevant because TPB is usually considered a good theory to explain past events but is less reliable in predictive terms.

Author Contributions: Conceptualization, Caterina Caprioli, Marta Bottero, Elena De Angelis; methodology, Caterina Caprioli, Marta Bottero, Elena De Angelis; Software, Caterina Caprioli; validation, Caterina Caprioli, Marta Bottero, Elena De Angelis; Data Curation, Caterina Caprioli, Marta Bottero, Elena De Angelis; writing-original draft preparation, Caterina Caprioli, Marta Bottero, Elena De Angelis; writing-review and editing, Caterina Caprioli, Marta Bottero, Elena De Angelis. All authors have read and agreed to the published version of the manuscript.

Funding: This research received no external funding.

Acknowledgments: Part of the work illustrated in the present paper has been developed in the research project titled VALIUM (Valuation for Integrated Urban Management) that has been supported by the Department of Regional and Urban Studies and Planning (DIST) of the Politecnico di Torino, Italy. The authors would like to thank Marialisa Pellegrini for her collaboration in the first stage of this research with her master degree thesis entitled "An ABM model for the evaluation of energy redevelopment interventions at urban scale: an application for the San Salvario neighbourhood in Turin" supervised by Bottero and PhD student Caterina Caprioli.

Conflicts of Interest: The authors declare no conflict of interest. 


\section{References}

1. Navarro-Yáñez, C.J.; Rodríguez-García, M.J. Urban policies as multi-level policy mixes. The comparative urban portfolio analysis to study the strategies of integral urban development initiatives. Cities 2020, 102, 102716. [CrossRef]

2. Bottero, M.; D'Alpaos, C.; Dell'Anna, F. Boosting Investments in Buildings Energy Retrofit: The Role of Incentives. In Smart Innovation, Systems and Technologies, Proceedings of the International Symposium on New Metropolitan Perspectives, Reggio Calabria, Italy, 22-25 May 2018; Springer: Cham, Switzerland, 2018; pp. 593-600.

3. Grubler, A.; Bai, X.; Buettner, T.; Dhakal, S.; Fisk, D.J.; Ichinose, T.; Keirstead, J.E.; Sammer, G.; Satterthwaite, D.; Schulz, N.B.; et al. Global Energy Assessment (GEA). In Urban Energy Systems; Johansson, T.B., Nakicenovic, N., Patwardhan, A., Gomez-Echeverri, L., Eds.; Cambridge University Press: Cambridge, UK, 2012; pp. 1307-1400.

4. Kourtit, K.; Nijkamp, P. Big data dashboards as smart decision support tools for i-cities-An experiment on stockholm. Land Use Policy 2018, 71, 24-35. [CrossRef]

5. Byrka, K.; Jedrzejewski, A.; Sznajd-Weron, K.; Weron, R. Difficulty is critical: The importance of social factors in modeling diffusion of green products and practices. Renew. Sust. Energ. Rev. 2016, 62, 723-735. [CrossRef]

6. D'Alpaos, C.; Bragolusi, P. Multicriteria prioritization of policy instruments in buildings energy retrofit. Valori e Valutazioni 2018, 21, 15-25.

7. MacAl, C.M.; North, M.J. Tutorial on agent-based modelling and simulation. In Proceedings of the Simulation Winter Conference, Orlando, FL, USA, 4 December 2005.

8. Huang, Q.; Parker, D.C.; Filatova, T.; Sun, S. A review of urban residential choice models using agent-based modeling. Environ. Plan. B Plan. Des. 2014, 41, 661-689. [CrossRef]

9. van Gent, W.P.C.; Musterd, S.; Ostendorf, W. Disentangling neighbourhood problems: Area-based interventions in western European cities. Urban Res. Pract. 2009, 21, 53-67. [CrossRef]

10. Bottero, M.; Caprioli, C.; Cotella, G.; Santangelo, M. Sustainable cities: A reflection on potentialities and limits based on existing eco-districts in Europe. Sustainaility 2019, 11, 5794. [CrossRef]

11. Luederitz, C.; Lang, D.J.; Von Wehrden, H. A systematic review of guiding principles for sustainable urban neighborhood development. Landsc. Urban Plan. 2013, 118, 40-52. [CrossRef]

12. Parker, D.C.; Manson, S.M.; Janssen, M.A.; Hoffmann, M.J.; Deadman, P. Multi-agent systems for the simulation of land-use and land-cover change: A review. Ann. Assoc. Am. Geogr. 2003, 93, 314-337. [CrossRef]

13. Railsback, S.F.; Grimm, V. Agent-Based and Individual-Based Modeling: A Practical Introduction; Princeton University Press: Princeton, NJ, USA, 2011.

14. Sopha, B.M.; Klöckner, C.A.; Hertwich, E.G. Adoption and diffusion of heating systems in Norway: Coupling agent-based modeling with empirical research. Environ. Innov. Soc. Transit. 2013, 8, 42-61. [CrossRef]

15. Snape, J.R.; Boait, P.J.; Rylatt, R.M. Will domestic consumers take up the renewable heat incentive? An analysis of the barriers to heat pump adoption using agent-based modelling. Energy Policy 2015, 85, 32-38. [CrossRef]

16. Kiesling, E.; Günther, M.; Stummer, C.; Wakolbinger, L.M. Agent-based simulation of innovation diffusion: A review. Cent. Eur. J. Oper. Res. 2012, 20, 183-230. [CrossRef]

17. Zhang, H.; Vorobeychik, Y. Empirically grounded agent-based models of innovation diffusion: A critical review. Artif. Intell. Rev. 2019, 52, 707-741. [CrossRef]

18. Hesselink, L.X.W.; Chappin, E.J.L. Adoption of energy efficient technologies by households-Barriers, policies and agent-based modelling studies. Renew. Sustain. Energy Rev. 2019, 99, 29-41. [CrossRef]

19. Haelg, L.; Waelchli, M.; Schmidt, T.S. Supporting energy technology deployment while avoiding unintended technological lock-in: A policy design perspective. Environ. Res. Lett. 2018, 13, 104011. [CrossRef]

20. Lee, M.; Hong, T. Hybrid agent-based modeling of rooftop solar photovoltaic adoption by integrating the geographic information system and data mining technique. Energy Convers. Manag. 2019, 183, 266-279. [CrossRef]

21. Schiera, D.S.; Minuto, F.D.; Bottaccioli, L.; Borchiellini, R.; Lanzini, A. Analysis of Rooftop Photovoltaics Diffusion in Energy Community Buildings by a Novel GIS- and Agent-Based Modeling Co-Simulation Platform. IEEE Access 2019, 7, 93404-93432. [CrossRef] 
22. Nuñez-Jimenez, A.; Knoeri, C.; Hoppmann, J.; Hoffmann, V.H. Can designs inspired by control theory keep deployment policies effective and cost-efficient as technology prices fall? Environ. Res. Lett. 2020, 15, 44002. [CrossRef]

23. Zhao, J.; Mazhari, E.; Celik, N.; Son, Y.J. Hybrid agent-based simulation for policy evaluation of solar power generation systems. Simul. Model. Pract. Theory 2011, 19, 2189-2205. [CrossRef]

24. Robinson, S.A.; Stringer, M.; Rai, V.; Tondon, A. GIS-integrated agent-based model of residential solar PV diffusion. In Proceedings of the 32nd USAEE/IAEE North American Conference, Anchorage, AK, USA, 28-31 July 2013; pp. 28-31.

25. Rai, V.; Sigrin, B. Diffusion of environmentally-friendly energy technologies: Buy versus lease differences in residential PV markets. Environ. Res. Lett. 2013, 8, 14022. [CrossRef]

26. Rai, V.; Robinson, S.A. Agent-based modeling of energy technology adoption: Empirical integration of social, behavioral, economic, and environmental factors. Environ. Model. Softw. 2015, 70, 163-177. [CrossRef]

27. Clean Energy for all Europeans. Energy Policy Framework: European Commission. Available online: https://ec.europa.eu/energy/topics/energy-strategy-and-energy-union/clean-energy-all-europeans_ en? redir=1 (accessed on 23 August 2020).

28. Watts, D.; Strogatz, S. Collective dynamics of 'small-world'networks. Nature 1998, 393, 440-442. [CrossRef] [PubMed]

29. Deffuant, G.; Amblard, F.; Weisbuch, G.; Faure, T. How can extremism prevail? A study based on the relative agreement interaction model. J. Artif. Soc. Soc. Simul. 2002, 5, 4.

30. Deffuant, G.; Neau, D.; Amblard, F.; Weisbuch, G. Mixing beliefs among interacting agents. Adv. Complex Syst. 2000, 3, 87-98. [CrossRef]

31. Ajzen, I. The theory of planned behavior. Organ. Behav. Hum. Decis. Process. 1991, 50, 179-211. [CrossRef]

32. Perri, C.; Giglio, C.; Corvello, V. Smart users for smart technologies: Investigating the intention to adopt smart energy consumption behaviors. Technol. Forecast. Soc. Chang. 2020, 155, 119991. [CrossRef]

33. Abreu, J.; Wingartz, N.; Hardy, N. New trends in solar: A comparative study assessing the attitudes towards the adoption of rooftop PV. Energy Policy 2019, 128, 347-363. [CrossRef]

34. Boeck, P.D.; Rosenberg, S. Hierarchical classes: Model and data analysis. Psychometrika 1988, 53, $361-381$. [CrossRef]

35. Ajzen, I. Constructing a TpB questionnaire: Conceptual and methodological considerations. J. Bus. Psychol. 2002. Available online: http://people.umass.edu/aizen/pdf/tpb.measurement.pdf (accessed on 23 August 2020).

36. Galam, S.; Wonczak, S. Dictatorship from majority rule voting. Eur. Phys. J. B 2000, 18, 183-186. [CrossRef]

37. Krause, U. A discrete nonlinear and non-autonomous model of consensus formation. In Communications in Difference Equations; Elaydi, S., Ladas, G., Popenda, J., Rakowski, J., Eds.; Gordon and Breach Publ.: Amsterdam, The Netherlands, 2000; pp. 227-236.

38. Dittmer, J.C. Consensus formation under bounded confidence. Nonlinear Anal. Theory Methods Appl. 2001, 47, 4615-4621. [CrossRef]

39. Hegselmann, R.; Krause, U. Opinion dynamics and bounded confidence models, analysis, and simulation. J. Artif. Soc. Soc. Simul. 2002, 5, 2.

40. Goles, E.; Martinez, S. Neural and Automata Networks; Kluwer: Dordrecht, The Netherlands, 1990.

41. Barabási, A.L.; Albert, R. Emergence of scaling in random networks. Science 1999, 286, 509-512. [CrossRef] [PubMed]

42. De Sola Pool, I.; Milgram, S.; Newcomb, T.; Kochen, M. The Small World; Norwood, N.J., Ed.; Ablex Publ.: New York, NY, USA, 1989.

43. Milgram, S. The small world problem. Psycology today. Psychology 1967, 2, 60-67.

44. Guare, J. Six Degrees of Separation: A Play; Vintage: New York, NY, USA, 1990.

45. Stokstad, E. Sustainable goals from UN under fire. Science 2015, 347, 702-703. [CrossRef]

46. Tisue, S.; Wilensky, U. NetLogo: Design and implementation of a multi-agent modeling environment. In Proceedings of the Conference on Social Dynamics: Interaction, Reflexivity and Emergence, Chicago, IL, USA, 7-9 October 2004.

47. Gestore Servizi Energetici: Rapporto Statistico Solare Fotovoltaico. Available online: https://www.gse.it/ documenti_site/Documenti\%20GSE/Rapporti\%20statistici/Solare\%20Fotovoltaico\%20-\%20Rapporto\%20Stat istico\%202018.pdf (accessed on 23 August 2020). 
48. Eurostat: Electricity Prices by Type of User. Available online: https://ec.europa.eu/eurostat/tgm/table.do? tab=table\&init $=1 \&$ language $=$ en \&pcode $=$ ten00117\&plugin $=1$ (accessed on 23 August 2020).

49. Dipartimento Attività Produttive: Lettera h, Articolo 16-bis del TUIR. Available online: https://www. brocardi.it/testo-unico-imposte-redditi/titolo-i/capo-i/art16.html?q=16+tuir\&area=codici (accessed on 23 August 2020).

50. ISTAT: Basi Territoriali e Variabili Censuarie. Available online: https://www.istat.it/it/archivio/104317 (accessed on 23 August 2020).

51. ISTAT: Spese per Consumi. Available online: http://dati.istat.it/Index.aspx?DataSetCode=DCCV SPEMEFAM (accessed on 28 September 2020).

52. ISTAT: Rapporto Annuale 2017. Available online: https://www4.istat.it/it/archivio/199318 (accessed on 23 August 2020).

53. Meadows, M.; Cliff, D. Reexamining the relative agreement model of opinion dynamics. J. Artif. Soc. Soc. Simul. 2012, 15, 4. [CrossRef]

54. Rogers, E.M. The Diffusion of Innovations, 5th ed.; Free Press: New York, NY, USA, 2003.

55. De Paoli, O.; Ricupero, M. Sistemi Solari Fotovoltaici e Termici. Strumenti per il Progettista; CELID: Torino, Italy, 2006.

56. Mokha, A.K. Impact of Green Marketing Tools on Consumer Buying Behaviour. Asian J. Manag. 2018, 9, 168-174. [CrossRef]

57. Paul, J.; Modi, A.; Patel, J. Predicting green product consumption using theory of planned behavior and reasoned action. J. Retail. Consum. Serv. 2016, 29, 123-134. [CrossRef]

58. ISTAT: Popolazione e Ambiente: Preoccupazioni e Comportamenti dei Cittadini in Campo Ambientale. Available online: https://www4.istat.it/it/files/2015/12/Popolazione-e-ambiente.pdf?title=Popolazione+e+ ambiente+-+22/dic/2015+-+Testo+integrale.pdf (accessed on 23 August 2020).

59. Weiss, J.; Dunkelberg, E.; Vogelpohl, T. Improving policy instruments to better tap into homeowner refurbishment potential: Lessons learned from a case study in Germany. Energy Policy 2012, 44, 406-415. [CrossRef]

60. Friege, J. Increasing homeowners' insulation activity in Germany: An empirically grounded agent-based model analysis. Energy Build. 2016, 128, 756-771. [CrossRef]

61. Friege, J.; Chappin, E. Modelling decisions on energy-efficient renovations: A review. Renew. Sustain. Energy Rev. 2014, 39, 196-208. [CrossRef]

62. Anable, J.; Lane, B.; Kelay, T. An Evidence Base Review of Public Attitudes to Climate Change and Transport Behaviour; The Department for Transport: London, UK, 2006.

63. Müller-Eie, D.; Bjørnø, L. The implementation of urban sustainability strategies: Theoretical and methodological implications for researching behaviour change. Int. J. Sustain. Dev. Plan. 2017, 12, 894-907. [CrossRef]

(C) 2020 by the authors. Licensee MDPI, Basel, Switzerland. This article is an open access article distributed under the terms and conditions of the Creative Commons Attribution (CC BY) license (http://creativecommons.org/licenses/by/4.0/). 